\title{
Destinasyon İmajı ve Algılanan Riskin, Davranışsal Niyete Etkisi: Bodrum Örneği
}

Uğurkan SAVAŞÇI, Çanakkale Onsekiz Mart Üniversitesi, Lisansüstü Eğitim Enstitüsü, Seyahat İşletmeciliği ve Turist Rehberliği Anabilim Dalı, ugurkansavasci@hotmail.com, Çanakkale, Türkiye, ORCID: 0000-0002-4258-4089

Hacı Mehmet YILDIRIM, Çanakkale Onsekiz Mart Üniversitesi, Turizm Fakültesi, Seyahat İşletmeciliği ve

Turizm Rehberliği Bölümü, hadjimehmet@gmail.com, Çanakkale, Türkiye, ORCID: 0000-0003-0718-7296

\section{Öz}

İmaj ve risk turistlerin seyahat öncesi algılarım etkilediği gibi seyahat sonrası algıların etkilemekte ve turistlerin davranışsal niyetini belirlemektedir. Bu kapsamda çalışmada Bodrum destinasyonunu ziyaret eden yabancı turistlerin algıladıkları imaj ve riskin, davranışsal niyet üzerindeki etkisinin belirlenmesi amaçlanmıştır. Aynı zamanda destinasyon imajının, algılanan risk üzerindeki etkisi de belirlenmeye çalışılmıştır. Araştırmada veriler, anket aracılı̆̆ıyla Bodrum destinasyonunu ziyaret eden yabancı turistlerden toplanmıştır. Toplanan anketler içerisinden analize uygun olmayanlar çıkarılmış ve 463 anket üzerinden istatistiki analizler gerçekleştirilmiştir. Araştırma sonuçlarına göre destinasyon imajının, algılanan risk üzerinde olumsuz ve anlaml bir etkiye sahip olduğu; destinasyon imajının, davranışal niyet üzerinde olumlu ve anlamlı bir etkiye sahip olduğu; algılanan riskin ise davranışsal niyet üzerinde bir etkisinin olmadı̆̆ı belirlenmiş̧ir.

Anahtar Kelimeler: Destinasyon imajı, algılanan risk, davranışsal niyet, Bodrum.

\section{Impact of Destination Image and Perceived Risk on Behavioral Intention: The Case of Bodrum}

\begin{abstract}
Image and risk affect the perceptions of tourists; their pre and post travel perceptions and determine the behavioral intention of the tourists. In this context, it was aimed to determine the effect of the perceived image and risk on behavioral intention by foreign tourists visiting Bodrum. At the same time, the effect of the destination image on the perceived risk was tried to be determined. The data for this study were collected via questionnaire from foreign tourists visiting Bodrum. Questionnaires that were not suitable for analysis were removed and statistical analysis was carried out on 463 questionnaires. According to the research results, the image of the destination has a negative and significant effect on the perceived risk; the image of the destination has a positive and significant effect on behavioral intention; it was determined that perceived risk had no effect on behavioral intention. Keywords: Destination image, perceived risk, behavioral intention, Bodrum.
\end{abstract}




\section{Giriş}

Destinasyon imajı bir kişinin belirli bir yer hakkında sahip olduğu bilgi, izlenim, önyargı ve düşüncelerin anlatımı olarak tanımlanabilmektedir (Özdemir, 2008). Destinasyon imajı, destinasyonun sahip olduğu özellikleri kapsamasından dolayı destinasyona özel bir kavramdır ve algılar bu doğrultuda şekillenmektedir. Destinasyon imajının turistler tarafından nasıl algılandı̆̆ının belirlenmesi, bir turistik destinasyonun turizm pazarındaki yerinin belirlenmesini sağlamaktadır. Yapılan çalışmalarda destinasyon imajının; destinasyon seçiminde, tekrar ziyaret ve tavsiye etme üzerinde önemli etkilerinin olduğu görülmektedir. Destinasyonların turizm sektöründe sahip oldukları imaj ile rakiplerine karşı farklılık yarattığı belirtilmektedir. Bu kapsamda oluşturulan destinasyon imajı turistlerin karar verme sürecinde ve seçimlerinde önemli bir rol oynamaktadır (Beerli ve Martin, 2004: 657; Chen, Lai, Petrick ve Lin, 2016: 27). Aynı zamanda destinasyonların sürdürülebilirliği için olumlu bir imaj oluşturulması gerektiği de belirtilmektedir (Pike, 2002: 542).

Destinasyon imajına ek olarak bir destinasyonun kişiler tarafından algılanan riskinin tercih etmede ve satın almada etkili olduğu görülmektedir. Algılanan risk kavramına bakıldığında "belirsizlik" ön plandadır. Ayrıca risk kavramı, bir ürün veya hizmetin kullanılmasında olası olumsuz sonuçlar ile ilgili belirsizlik hissi olarak tanımlanmaktadır. Bu açıdan bir destinasyonun, turistler tarafından algılanan riskinin belirlenmesi hem destinasyonun olumsuzluklarının belirlenip giderilmesine hem de destinasyon imajında olduğu gibi destinasyonun turizm pazarındaki yerinin belirlenmesine olanak sağlayabilmektedir. Algılanan risk kavramının turizm alanında önemli olduğu görülmektedir. Turizmde risk algısının tanımına bakıldığında turistin, seyahat hizmetlerini satın alma ve tüketme işlemi sırasında, destinasyonda deneyimlediği ve algıladığı olgu olarak tanımlandığı görülmektedir (Tsaur, Tzeng ve Wang, 1997: 797; Reisinger ve Mavondo, 2005: 213). Turistlerin tatil için gidecekleri destinasyona karar vermelerinde algilanan risk rol oynamaktadır (Roehl ve Fesenmaier, 1992: 20). Bu kapsamda destinasyonun sahip olduğu risk algısı turist tercihlerini etkilemekte ve turistleri yönlendirmektedir. Turistik ürünün farklı bileşenlerden oluşması turistler için algılanan risk boyutlarının farklılık göstermesine olanak sağlamakta ve farklı yapıların oluşmasına neden olmaktadır. Bu yapıların anlaşılması ile turistik tüketici davranışlarının anlaşılabileceği belirtilmektedir (Hunter-Jones, Jeffs ve Smith, 2008: 240). Genel olarak algılanan riskin hem turist açısından hem de turistik destinasyona bağlı tüm paydaşlar açısından etkin bir role sahip olduğu ve davranışsal niyetlerin belirlenmesinde önemli olduğu söylenebilir.

Davranışsal niyet ise turizm açısından önem arz etmektedir. Davranışsal niyet, bireyin gelecekte bir davranışı gerçekleştirmek veya gerçekleştirmemek doğrultusunda yaptığı planların derecesi olarak belirtilmektedir. Bu kapsamda davranışsal niyetler, turistlerin deneyimleri ve algıları doğrultusunda şekillenen davranışlar olarak karşımıza çıkmaktadır. Yapılan çalışmalarda, destinasyon imajının ve algılanan riskin davranışsal niyet üzerinde önemli etkilere sahip olduğu görülmektedir (Chew ve Jahari, 2014; Chapuis vd., 2015; Khasawneh ve Alfandi, 2019). Bu doğrultuda destinasyon imajı, algılanan risk ve davranışsal niyet konularının çalışıldığı görülmektedir. Bu araştırmayla da Türkiye' de önemli bir turistik destinasyon olan Bodrum ilçesini ziyaret eden yabancı turistlerin algıladıkları destinasyon imajının ve destinasyon riskinin belirlenmesi, davranışsal niyet üzerindeki etkilerin ortaya çıkarılması amaçlanmaktadır. Bodrum açısından böyle bir araştırmaya rastlanmamış olması çalışmanın önemini belirlemektedir. Araştırma sonuçlarının destinasyona yönelik imajın, algılanan riskin ve davranışsal niyetlerin belirlenmesi kapsamında destinasyonda bulunan hem turizm işletmeleri hem de kamu kurum ve kuruluşları açısından önemli bilgiler sağlayacağı düşünülmektedir. Bu doğrultuda araştırmanın destinasyon gelişiminde önemli olacağı belirtilebilir. Her çalışmada olduğu gibi yapılan bu araştırmanın Bodrum'u ziyaret eden belirli sayıda yabancı turist ile belirli bir zaman aralığında gerçekleştirilmesi araştırmanın sınırlılığını oluşturmaktadır. Yapılan çalışmanın turistik bir destinasyonun, imajının ve algılanan riskinin tespit edilmesi; bunların davranışsal niyet üzerindeki etkilerinin belirlenmesi ile literatüre destek sağlaması ve Bodrum destinasyonunda yapılıyor olmasından dolayı önem arz edeceği düşünülmektedir. 
Savaşçı U. \& Yıldırım, H. M. (2021). Impact of Destination Image and Perceived Risk on Behavioral Intention:

The Case of Bodrum. GSI Journals Serie A: Advancements in Tourism, Recreation and Sports Sciences (ATRSS), 4 (2): 17-36

\section{Literatür Taramas1}

\subsection{Destinasyon İmaj1}

Destinasyonların sahip olduğu özellikler ve ayrıldıkları türler turistlerin tercihlerini etkileyip, satın alma niyetlerini belirleyebilmektedir. Bu etkenlerden birisi destinasyonun sahip olduğu imajdır. Destinasyon imajı bir kişinin belirli bir yer hakkında sahip olduğu bilgi, izlenim, önyarg1 ve düşüncelerin bütünü olarak tanımlanabilir (Baloğlu ve McCleary, 1999: 870). Turistler, destinasyon hakkında kaynaklardan gelen bilgilerin işlenmesiyle birlikte bir imaj yaratmaktadırlar. Destinasyonlar da sahip oldukları özelliklerine göre bir imaj yaratmaya çalışmaktadırlar. Potansiyel turistlerin, turistik destinasyon ile ilgili algıladıkları imaj, destinasyonun geleceğini belirleyen faktörlerden birisidir. Bu kapsamda Beerli ve Martin (2004) destinasyon imajı oluşumuna etki eden unsurları 9 faktörde belirtmişlerdir. Bu faktörler;

- Doğal Kaynaklar (iklim - doğal alanlar - flora ve fauna çeşitliliği vb.)

- Genel Altyapı (yollar / limanlar - ulaşım - sağlık - iletişim - ticaret vb.)

- Turizm Altyapısı (otel - restoran - bar - turistik merkezler vb.)

- Eğlence Yerleri (tema parklar - alışveriş merkezleri vb.)

- Kültür, Tarih ve Sanat (müzeler - festivaller - el sanatları - gastronomi - folklor - inanç - yaşam tarzı vb.)

- Siyasi ve Ekonomik Faktörler (politik istikrar - güvenlik - fiyatlar vb.)

- Doğal Çevre (nüfus - trafik - temizlik vb.)

- Sosyal Çevre (yerel halk - yaşam kalitesi - dil)

- Destinasyon Atmosferi (lüks - egzotik - stresli - eğlenceli vb.)

Destinasyon imajı bileşenlerine bakıldığında ise çalışmaların çoğunda destinasyon imajının bilişsel ve duygusal bileşenlerden oluştuğu ifade edilmektedir (Hosany, Ekinci ve Yüksel, 2007: 64). Ayrıca bilişsel imajın, duygusal imajın öncüsü olduğu ve bu iki bileşeninde genel imajı etkilediği belirtilmektedir (Beerli ve Martin, 2004: 658). Baloğlu ve McCleary (1999) ile Beerli ve Martin (2004) destinasyon imajı bileşenlerini bilişsel, duygusal ve genel olarak belirtmişlerdir. Bilişsel imaj, bir kişinin bir destinasyon hakkında sahip olduğu bilgi ve inançların ifadesi; duygusal imaj ise bir kişinin bir destinasyona karşı olan duygularının ve hissettiklerinin ifadesi olarak tanımlanmıştır. Son olarak bilişsel ve duygusal imajın birleşiminden genel imajın oluştuğu belirtilmektedir. Genel imaj, bir destinasyonun turistlerin zihninde nasıl sınıflandırıldığının anlaşılması için önem arz etmektedir (Stepchenkova ve Morrison, 2008: 550). Bu doğrultuda destinasyon imajının hem destinasyonun özeliklerine hem de turistlerin özelliklerine göre karşılıklı bileşenlerden oluştuğu görülmektedir.

Turizm literatüründe destinasyon imajı, algılanan risk ve davranışsal niyet ile ilgili yapılan çalışmalarda değişkenlerin birbirleriyle ilişkili olduğu görülmektedir. Destinasyon imajı ve davranışsal niyetleri ele alan çalışmalarda imajın, niyeti doğrudan ve aracılık etkisiyle etkilediği belirtilmektedir (Bigne vd., 2001; Chen ve Tsai, 2007; Atılgan İnan vd., 2011; Sevim vd., 2013; Zhang vd., 2014; Stylos vd., 2016; Loi vd., 2017; Yüce vd., 2019).

Tavitiyaman ve Qu (2013) çalışmalarında destinasyon imajının ve genel memnuniyetin Tayland'a seyahat eden turistlerin davranışsal niyetleri üzerindeki etkilerini araştırmışlardır. Bulgular doğrultusunda destinasyon imajı boyutlarından otel ve restoranların kalitesi ile kültürel ve doğal cazibe merkezlerinin, genel memnuniyeti önemli derecede etkilediğini; ayrıca genel memnuniyetin, davranışsal niyetleri önemli derecede etkilediğini belirtmişlerdir. Buna ek olarak algılanan riskin; destinasyon imajı, genel memnuniyet ve davranışsal niyetler arasındaki aracılık etkisini araştırmışlardır. Bu doğrultuda düşük seviyede algılanan riske sahip turistlerin, yüksek seviyede algılanan riske sahip olan turistlere istinaden daha olumlu destinasyon imajı, genel memnuniyet ve davranışsal niyetlere sahip olduğu sonucuna ulaşmışlardır.

Ateşoğlu ve Türker (2014) ise çalışmalarında Antalya, İstanbul, Muğla ve Kapadokya'yı ziyaret eden turistlerin destinasyon tercihinde, ülke imajının algılanan risklere etkisini belirlemeyi amaçlamışlardır. 
Katılımcıların ziyaret öncesi risk algılarının ziyaret sonrasına göre daha olumsuz olduğu ve ilk kez ziyaret edenlerin risk algılarının yüksek olduğu tespit edilmiştir. Sonuçlara göre ülke imajı ile algılanan risk arasında negatif yönlü ilişkinin olduğu ve Türk insanı imajı, Türkiye imajı, medyada yer alan haberlerin algılanan riskleri etkilediği belirtilmektedir.

Harun ve arkadaşları (2018) Malezya'nın Güneydoğu Kıyısını ziyaret eden yerli ve yabancı turistlerin algılarını belirlemek için bir araştırma yapmışlardır. Araştırmada; turistlerin algıladıkları, destinasyon imajını ve destinasyon riskini belirlemek; imaj ve riskin, tekrar ziyaret üzerindeki etkilerini tespit etmek amaçlanmıştır. Sonuç olarak; destinasyon imajının, tekrar ziyaret etme niyeti üzerinde önemli bir etkisinin olduğunu ancak algılanan riskin, tekrar ziyaret üzerinde önemli bir etkisinin olmadığını belirlemişlerdir.

\subsection{Algilanan Risk}

Algılanan risk kavramı ilk olarak Bauer (1960) tarafından “bir kararın sonucunun belirsizliği” olarak açıklanmıştır (Aktaran: Lim, 2003: 218). Gartner (1989) algılanan risk kavramını, seçim sonucunda beklenen zarar olarak tanımlamaktadır. Schifmann ve Kanuk (2000) algılanan risk kavramını, verilen satın alma kararı sonucunda oluşacak sonuçların belirsizliği olarak tanımlamışlardır. Algılanan risk kavramının tanımlarında “belirsizlik" kavramının vurgulandığı görülmektedir (Frewer vd., 2003: 77).

Araştırmacılar, algılanan risk kavramının temelinde satın alma amacının olduğunu belirtmektedirler. Tüketici belirli bir amaç doğrultusunda ürün veya hizmeti satın almaktadır ve deneyimlemeden sonuçlarını bilemediği için risk algılamaktadır (Gronhaug, 1972: 246; Gao, 2006: 334). Bu durum algılanan risk ve tüketici davranışlarının ilişkisini ortaya çıkarmaktadır. Algılanan riskin, bir ürün veya hizmeti satın almaya karar verme sürecinde başlayan ve sonuçları öğrenene kadar devam eden belirsizlik olduğu söylenebilir. Algılanan risk, ürün ve hizmet satın alma sürecinde tüketicinin satın alma sonucu oluşabilecek olumsuzlukları değerlendirmesi olarak belirtilebilir.

Turizmde de algılanan risk kavramı turistik tüketici davranışlarını etkileyen bir faktör olarak belirtilmektedir. Turistler seyahat kararlarını verirken gerçek riskler yerine, algıladıkları riskleri değerlendirmektedir çünkü deneyimlemeden gerçek sonuçlara ulaşılamamaktadır (Mitchell ve Vassos, 1998: 50). Algılanan risk türleri kişiden kişiye, bölgeden bölgeye farklılık göstermektedir. Algılanan risk türlerini belirlemeye yönelik yapılan çalışmalara Jacoby ve Kaplan (1972) risk algısını sınıflandırmışlar ve bu boyutları; finansal risk (maddi kayıp), fiziksel risk (sağlık kaybı), psikolojik risk (şahsi imaj kaybı), sosyal risk (sosyal statü kaybı) ve performans riski (fonksiyonel kayıp) olarak belirlemişlerdir. Belirlenen bu beş faktör algılanan riskin farklı boyutlardan oluştuğunu ve algılanan riskin hem somut hem de soyut özellikleri kapsayan bir değişken olduğunu göstermektedir. Algılanan risk kişinin öznel algısını yansıttığ1 için kişilere ve ürün veya hizmete göre faktörlerin şiddetinin farklı olduğu söylenebilir.

Turizmde algılanan risk alanında Roehl ve Fesenmaier (1992) tarafından yapılan çalışma, algılanan risk türlerine öncülük etmektedir. Yapılan çalışmada yedi boyut belirlenmiş ve bu faktörlerin algılanan risk türlerini oluşturduğu belirtilmiştir. Bu boyutlar alınan hizmet karşılığında oluşacak sonuçların belirsizliğini ortaya koymaktadır. Algılanan risk türleri; donanım riski (mekanik ve organizasyonel sorunlar), finansal risk (para kaybı olasılığı), fiziksel risk (sağlık sorunları), psikolojik risk (alınan hizmetin, kişinin imajına veya kişiliğine uymama olasılığı), memnuniyet riski (memnuniyetsizlik olasılığı), sosyal risk (sosyal statü kaybı) ve zaman riski (boşa zaman harcama olasılığı) olarak belirtilmiştir. Belirtilen bu boyutlar hizmet sektöründe, genel algılanan risk türlerini oluşturmaktadır (Reisinger ve Mavondo, 2005: 213). Roehl ve Fesenmaier (1992) çalışma sonucunda turizmde risk algısını; fiziksel ekipman riski, tatil riski ve destinasyon riski olarak belirtmişlerdir.

Turizm literatüründe algılanan risk, destinasyon imajı ve davranışsal niyet ile ilgili yapılan çalışmalarda değişkenlerin birbirleriyle ilişkili olduğu görülmektedir. Destinasyon risk algısı ve davranışsal niyet çalışmalarında da niyetin, risk algısından doğrudan ve dolaylı olarak olumsuz açıdan etkilendiği belirtilmektedir (Floyd vd., 2004; Çetinsöz ve Ege, 2013; Hasan vd., 2017). 
Chew ve Jahari (2014) Japonya'da yaşanan doğal afetler sonrasında, Japonya'yı ziyaret eden Malezyalı turistlerin algıladıkları destinasyon imajının, algılanan risk ve tekrar ziyaret ilişkisinde aracılık rolünün olup olmadığını araştırmışlardır. Araştırma bulguları, algılanan sosyo-psikolojik ve finansal riskin hem bilişsel hem de duygusal imajı etkilediğini, algılanan fiziksel riskin ise imaj üzerinde önemli bir etkisinin olmadığını göstermektedir. Aynı zamanda imajın, algılanan sosyo-psikolojik ve finansal risk ile tekrar ziyaret arasında aracılık rolünün olduğunu belirlemişlerdir. Çalışmada olumlu destinasyon imajının, olumlu davranışsal niyetleri meydana getirdiği; olumsuz destinasyon imajının, olumsuz davranışsal niyetleri meydana getirdiği belirtilmektedir.

Khasawneh ve Alfandi (2019) yaptıkları çalışmada algılanan riskin ve destinasyon imajının, davranışsal niyetler üzerindeki etkisini belirlemeyi amaçlamışlardır. Bulgular algılanan risk faktörlerinden finansal ve performans riskinin hem genel destinasyon imajı hem de davranışsal niyetler üzerinde doğrudan etkili olduğunu göstermektedir. Fiziksel, zaman ve sosyo-psikolojik risklerin ise imaj ve davranışsal niyetler üzerinde önemli etkilerinin olmadığını belirlemişlerdir. Genel destinasyon imajının davranışsal niyetleri doğrudan etkilediği belirtilmektedir.

Destinasyonların turizm sektöründe sahip oldukları imaj sayesinde rakiplerine karşı farklılık yarattığı belirtilmektedir. Bu kapsamda oluşturulan destinasyon imajı turistlerin karar verme sürecinde ve seçimlerinde önemli bir rol oynamaktadır (Beerli ve Martin, 2004: 657; Chen, Lai, Petrick ve Lin, 2016: 27). Turistlerin tercihlerini etkileyen önemli bir diğer faktör ise algılanan risktir. Turistler seyahat kararlarını verirken gerçek riskler yerine, algıladıkları riskleri değerlendirmektedir; bunun sebebi deneyimlemeden gerçek sonuçlara ulaşılamamasıdır (Mitchell ve Vassos, 1998: 50). İmaj ile ilgili yapılan çalışmalar turistik destinasyonun olumlu özelliklerini tanımlarken; risk algısı ile ilgili yapılan çalışmalar turistik destinasyonun olumsuz özelliklerini tanımlamaktadır (Perpina, Camprubi ve Prats, 2019: 3).

Destinasyon imajı ve algılanan risk kavramlarının birlikte ele alındığı çalışmalarda iki kavramında birbiriyle ilişkili olduğu görülmektedir (Tavitiyaman ve Qu, 2013; Chew ve Jahari, 2014; Ateşoğlu ve Türker, 2014; Biswakarma, 2017). Ayrıca çalışmalarda değişkenlerin aracılık rollerinin olduğu da belirtilmektedir. Bu doğrultuda bu çalışmanın birinci araştırma hipotezi “Algılanan destinasyon imajı, algılanan riski etkiler" olarak belirlenmiştir.

- H1: Algılanan destinasyon imajı, algılanan riski etkiler.

\subsection{Davranışsal Niyet}

Davranışsal niyet kavramı belirli bir davranışı gösterme konusunda, bireyin öznel olasılı̆̆ıdır. Anderson (1983) davranışsal niyeti, belirli bir ortamda bireyin belirli bir davranışla ilgili beklentileri olarak açıklamaktadır. Ayrıca davranışsal niyet gelecekte bir davranışı gerçekleştirmek ya da gerçekleştirmemek yönünde birey tarafından yapılan planların derecesi olarak tanımlanmaktadır (Warshaw ve Davis, 1985: 214). Tüketici açısından bakıldığında davranışsal niyet, müşterinin bir işletmeye veya bir hizmeti almaya devam edeceğinin ya da terk edeceğinin bir göstergesi olarak belirtilmektedir (Zeithaml, Berry ve Parasuraman, 1996: 33; Yang, Gu ve Cen, 2011: 28). Davranışsal niyet, gelecekteki davranışların öngörüsü olarak belirtilmekte ve bu açıdan turizm kapsamında önem arz ettiği görülmektedir. Turist davranışlarının; ziyaret öncesi karar verme sürecini, ziyaret sürecindeki deneyimleri, deneyimlerin değerlendirilmesini ve ziyaret sonrası davranışsal niyetleri kapsayan davranışlar olduğu belirtilmektedir (Chen ve Tsai, 2007: 1115).

Davranışsal niyetler, bireylerin bilgilerinin, duygularının ve deneyimlerinin değerlendirmeleri doğrultusunda davranış eğilimleridir ve davranışsal niyetlerin olumlu ve olumsuz davranışsal niyetler olarak ayrıldığ görülmektedir (Koo, Byon ve Baker 2014: 129). Tekrar satın alma / yeniden satın alma, tavsiye / olumlu ağızdan ağıza iletişim, övme, çapraz satın alma, artan kullanım ve daha fazla ödeme davranışlarının olumlu davranışsal niyetler olduğu görülmektedir. Olumsuz davranışsal niyetlerin ise şikayet, olumsuz ağızdan ağıza iletişim ve değiştirme / ayrılma davranışlarının olduğu görülmektedir (Zeithaml vd., 1996). 
Turizm literatüründe davranışsal niyet, destinasyon imajı ve algılanan risk ve ile ilgili yapılan çalışmalarda değişkenlerin birbirleriyle ilişkili olduğu görülmektedir. Chapuis ve arkadaşları (2015) turistlerin, Kolombiya hakkındaki algılanan risk, imaj ve ziyaret etme ilişkisini araştırmışlardır. Çalışmada, destinasyon imajının ve algılanan riskin, ziyaret etme niyetini etkilediği sonucuna ulaşmışlardır. Biswakarma (2017) ise Nepal'in destinasyon imajının ve algılanan riskinin, turistlerin davranışsal niyetleri üzerindeki etkisini araştırmıştır. Bulgular destinasyon imajının ve algılanan riskin, turistlerin davranışsal niyetlerini etkilediğini göstermektedir. Ek olarak algılanan riskin, destinasyon imajı ve davranışsal niyetler arasında aracılık etkisinin olduğu belirtilmektedir.

Davranışsal niyet, gelecekte bir davranışı gerçekleştirmek ya da gerçekleştirmemek yönünde birey tarafından yapılan planların derecesi olarak tanımlanmaktadır (Warshaw ve Davis, 1985: 214). Yapılan çalışmalarda davranışsal niyetler, gelecekteki davranışların öngörüsü olarak belirtilmekte ve turizm alanında önem arz etmektedir. Davranışsal niyetler ile ilgili yapılan çalışmalara bakıldığında davranışsal niyetlerin boyutlarının değerlendirildiği görülmektedir.

Turizm alanında yapılan çalışmalarda destinasyon imajı faktörünün davranışsal niyetleri hem olumlu hem de olumsuz açıdan etkilediği belirtilmektedir (Wang ve Hsu, 2010; Atılgan İnan vd., 2011; Sevim vd., 2013; Zhang vd., 2018; Harun vd., 2018). Yapılan çalışmalara ve açıklamalara istinaden $\mathrm{H}_{2}$ şu şekilde ifade edilmiştir;

- $\mathrm{H}_{2}$ : Algılanan destinasyon imajı, davranışsal niyeti etkiler.

Algılanan risk ile davranışsal niyetler çalışmalarına bakıldığında davranışsal niyetlerin hem doğrudan hem de dolaylı olarak algılanan riskten etkilendiği görülmektedir (Kozak vd., 2007; An vd., 2010; Çetinsöz ve Ege, 2013; Artuğer, 2015; Biswakarma, 2017; Hasan vd., 2017). Yapılan çalışmalara ve açklamalara istinaden $\mathrm{H}_{3}$ şu şekilde ifade edilmiştir;

- $\mathrm{H}_{3}$ : Algılanan risk, davranışsal niyeti etkiler.

\section{Yöntem}

Destinasyon imajının ve algılanan riskin belirlenmesiyle bir destinasyonun turistler tarafından neden tercih edildiği veya edilmediği belirlenebilmektedir. Ayrıca turistlerin davranışsal niyetlerinin belirlenmesi bir destinasyonun turizm pazarındaki devamlılığı için önem arz etmektedir. Bu kapsamda çalışmanın amacı, popüler bir turistik destinasyon olan Bodrum ilçesini ziyaret eden yabancı turistlerin algıladıkları destinasyon imajının ve destinasyon riskinin tespit edilmesi; imaj ve riskin, davranışsal niyet üzerindeki etkilerinin belirlenmesidir.

Muğla İl Kültür ve Turizm Müdürlüğü verilerine göre 2019 yılında Muğla ilini ziyaret eden yabancı turist sayısı 3.068,796 kişi olarak belirlenmiştir. Bodrum sınır kapılarından giriş yapan turist sayısı ise 1.209,655 kişi olarak belirlenmiştir (Muğla İl Kültür ve Turizm Müdürlüğü, 2020). Belirli evrenler için kabul edilebilir örnek büyüklüklerine bakıldığında 100,000 ve üzeri evren büyüklüğünün, örneklem büyüklüğü 384 olarak belirtilmektedir (Sekaran, 2003'den aktaran Coşkun vd., 2017: 144). Araştırmada örneklemi belirlemek için örnekleme yöntemi olarak "kolayda örnekleme” yönteminden yararlanılmıştır. Araştırma kapsamında Bodrum destinasyonunu ziyaret eden yabancı turistlerden 476 anket toplanmıştır. Veri analizine uygun olmayan 13 anket değerlendirilmeye alınmamış ve toplamda 463 anket istatistiki analizlere tabi tutulmuştur.

Araştırmada öncelikle destinasyon imajı, algılanan risk ve davranışsal niyet konuları ile ilgili literatür incelemesi yapılmıştır. İnceleme sonucunda veri toplama için anket formu oluşturulmuştur. Anket formu iki bölümden oluşmaktadır. İlk bölüm destinasyon imajı, algılanan risk ve davranışsal niyet ile ilgili 53 ifadeyi içermektedir. Ölçek derecelendirmesi Likert ve Semantik ölçek olarak sunulmuştur. İlk olarak destinasyon imajı ölçeği, bilişsel imaja ait 14 ifadeden, algılanan risk ölçeği 30 ifadeden, davranışsal niyet ölçeği 5 ifadeden oluşturulmuş ve 5’li Likert ölçek (1-Kesinlikle Katılmıyorum / . . / 5-Kesinlikle 
Katıllyorum) ile sunulmuştur. Destinasyon imajı ölçeğine, duygusal imaja ait 4 ifadeden oluşan $4^{\prime}$ lü Semantik ölçek eklenmiştir. Ayrıca destinasyon imajı ölçeğinden genel imaja ait 1 ifade de 7 'li Semantik ölçek olarak anketin ikinci bölümünde yer almaktadır. Anket formunun ikinci bölümünde ise katılımcıların betimleyici özelliklerini belirlemek için 16 soru oluşturulmuştur. Araştırma verileri yabancı turistlerden toplanacağ için İngilizce dilinde olan destinasyon imajı, algılanan risk ve davranışsal niyet ölçeklerinin ifadeleri çalışma alanına uyarlanmıştır.

Destinasyon imajı ölçeği için, Baloğlu ve McCleary (1999) çalışmasından yararlanılmıştır. Algılanan risk ölçeği için Fuchs ve Reichel (2006) çalışmasından yararlanılmıştır. Davranışsal niyet ölçeği için Zeithaml, Berry ve Parasuraman (1996) çalışmasından yararlanılmıştır. Davranışsal niyet ölçeğinde sadakat boyutu ele alınmıştır. Verilerin toplanması amacıyla anket formu, internet ve yüz yüze görüşme yoluyla katılımcılara ulaştırılmış ve veriler, 15 Ağustos - 15 Eylül 2019 tarihleri arasında Bodrum destinasyonunda toplanmıştır.

Çalışma kapsamında destinasyon imajı, algılanan risk ve davranışsal niyet ölçümü için kullanılan ölçeklere güvenirlik analizi yapılmış ve değerlerin şartları karşıladığı görülmüştür. Sonuçlara göre 14 ifadeli bilişsel imaj ölçeğinin Cronbach'ın Alfa değeri 0,859; 29 ifadeli algılanan risk ölçeğinin Alpha değeri 0,966; 5 ifadeli davranışsal niyet ölçeğinin Alfa değeri 0,870 olarak belirlenmiştir. İçsel tutarlılığın ölçümünde en yaygın yöntem Alpha katsayısıdır. Alpha değeri 0 ile 1 arası değerler almaktadır. Bu değerin genel olarak en az 0,7 olması arzu edilmektedir. Ancak bazı çalışmalarda bu değerin 0,5'e kadar kabul edildiği de görülmektedir (Çoşkun vd., 2017: 133).

Yapılacak analizlerin belirlenmesi için verilerin normal dağılım sağlayıp sağlamadı̆̆ı incelenmiştir. Bu doğrultuda verilerin normal dağılım gösterip göstermediğine yönelik bilgi veren çarpıklık ve basıklık değerleri önem arz etmektedir. Analizler sonucunda belirlenen değerlerin çarpıklık değeri kapsamında \pm 2 ile \pm 3 aralığında olduğu, basıklık değeri kapsamında \pm 7 ile \pm 8 aralığında olduğu görülmektedir (West vd., 1995; Kline, 1998). Toplanan veriler neticesinde ulaşılan örnek boyutunun 463 olduğu göz önüne alındığında verilerin normal dağılım sağladığı söylenebilir (Coşkun vd., 2017: 179).

\section{Bulgular}

Bu bölümde araştırmanın örneklemini oluşturan turistlerin betimleyici özellikleri yer almaktadır. İlk olarak katılımcıların demografik özelliklerine yer verilmiş daha sonra katılımcıların seyahat özellikleri, ziyaret sebepleri ve risk düşüncelerine değinilmiştir. Demografik özellikler; cinsiyet, milliyet, medeni durum, eğitim, yaş, meslek ve gelir gibi katılımcılara ait özellikleri kapsamaktadır. Araştırmaya katılan turistlerin cinsiyete göre dağılımlarına bakıldığında kadın (\%55) katılımcıların erkek (\%45) katılımcılara oranla daha fazla olduğu görülmektedir. Katılımcıların yaş dağılımlarına bakıldığında 18-25 yaş arası $(\% 31,3)$ turistlerin daha fazla olduğu görülmekte ve bu yaş grubunu sirasılyla 26-33, 34-41, 42-49, 50 ve üstü yaş grubu takip etmektedir. Katılımcılar milliyetleri açısından değerlendirildiğinde Polonyalı turistlerin (\%22,2) çoğunlukta olduğu görülmektedir. Polonyalı turistleri, İngiliz, Ukraynalı, Hollandalı, Fransız, Rus, Alman, Belçikalı, Romen turistler izlemektedir. Katılımcıların medeni durum açısından evli (\%54) oranının, bekâr (\%46) oranına göre daha fazla olduğu görülmektedir. Çocuk durumu açısından ise katılımcıların çoğunluğunun çocuk sahibi olmadığı (\%63) belirlenmiştir. Katılımcıların eğitim durumlarına bakıldığında Bodrum'u ziyaret eden turistlerin çoğunlukla üniversite eğitimi $(\% 64,6)$ almış veya alan kişiler olduğu görülmektedir. Meslek açısından bakıldığında işçi grubu $(\% 57,5)$ oranının çoğunlukta olduğu görülmektedir. İşçi grubunu sırasıyla öğrenci, serbest meslek, memur, ev hanımı, emekli ve işsiz grupları takip etmektedir. Katılımcıların gelir dağılımlarına bakıldığında 1501-2500 € $(\% 25,7)$ gelir düzeyinin çoğunlukta olduğu görülmektedir.

Katılımcların seyahat özelliklerine ait bulgulara bakıldığında, bu başlık altında yedi değişkene yer verilmiştir. Seyahat özellikleri; turistin destinasyondaki seyahat partneri, turistin destinasyonu ziyaretindeki seyahat türü, turistin uluslararası seyahat deneyimi, turistin önceden Bodrum'da bulunup 
bulunmadığı, turistin önceden Türkiye'de bulunup bulunmadığı, Türkiye'de bulunduysa son ziyaret ettiği destinasyon ve Bodrum destinasyonunu tekrar ziyaret edip etmeyeceği konularında bilgi sağlamaktadır.

Katılımcıların seyahat partneri dağılımlarına bakıldığında Bodrum destinasyonunda aileleri ile seyahat edenlerin $(\% 65,2)$ çoğunlukta olduğu görülmektedir. Aile grubundan sonra seyahatlerin arkadaşlarla ve yalnız olarak gerçekleştiği söylenebilir. Katılımcıların tercih ettikleri seyahat türü dağılımında Bodrum destinasyonuna yönelik paket tur (\%78) seyahatinin, bireysel (\%22) seyahatten daha fazla olduğu görülmektedir. Katılımcların \%95'i uluslararası seyahat deneyimine sahip turistlerdir. Katılımcıların \%80'i daha önceden Bodrum destinasyonunda bulunmamış turistlerden oluşmaktadır. Katılımcıların önceki seyahatlerinde Türkiye'de bulunma oranına bakıldığında \%55'inin Türkiye'de bulunmadığı, $\% 45^{\prime}$ inin Türkiye'de bulunduğu belirlenmiştir. Türkiye'de bulunan turistlerin seyahat ettikleri son destinasyonlarda Antalya $(\% 6,5)$ destinasyonunun çoğunluğa sahip olduğu görülmektedir. Antalya'yı takiben İstanbul, Alanya, Kemer, Side, Bodrum, Marmaris destinasyonları bulunmaktadır. Son olarak turistlerin \%91'inin Bodrum destinasyonunu tekrar ziyaret edebilecekleri belirlenmiştir.

Katılımcıların Bodrum destinasyonunu ziyaret sebepleri de incelenmiştir. Katılımcılar Bodrum destinasyonunu ziyaretlerinin birinci sebebi olarak deniz-kum-güneş olanağını belirtmişlerdir. Bu grubu takiben sırasıyla; doğal güzellikler, eğlence, kültür-tarih-sanat, alışveriş, mimari, mavi yolculuk, sağlık, spor, inanç, festival, etkinlikler olanakları bulunmaktadır. Araştırmada katılımcıların Bodrum destinasyonuna yönelik risk düşünceleri yer almaktadır. Bulgular, katılımcıların çoğunluğunun Bodrum destinasyonuna yönelik risk düşüncesinin bulunmadığını göstermektedir. Bu grubu takiben trafik, kalabalık, pahalılık, güvensizlik, hırsızlık, düzensiz kentleşme düşünceleri Bodrum destinasyonuna yönelik risk düşüncelerini oluşturmaktadır.

\subsection{Açıklayıcı Faktör Analizi (AFA) Bulguları}

Faktör analizi sonucunda ortaya çıkan değerlerin bazı şartları sağlaması gerekmektedir. Faktör analizinin uygunluğunu gösteren $\mathrm{KMO}$ değerinde 0,5 ve 1,0 arası değerler kabul edilmektedir. 0,5'in altındaki değerler faktör analizinin veri seti için uygun olmadığını göstermektedir. Artan örnek boyutu, ortalama korelasyonları, değişken sayısı ve azalan faktör sayısı KMO değerinin artmasına olanak sağlamaktadır (Coşkun vd., 2017: 274). Bartlett küresellik testinin anlamlılı̆̆ önem arz etmektedir. Bu değerin 0,05'den küçük olması gerekmektedir. Faktör yükü değerinin de en az 0,40 olması tavsiye edilmektedir (Kozak, 2015:150). Değişkenlerin belirli faktörlere yüksek yüklemeler yapmasının sağlanması için faktör eksen döndürme işlemi yapılmaktadır. Bu araştırmada faktör analizi yapılırken "varimax" döndürme yönteminden yararlanılmıştır. Bu yöntem analizlerde en yaygın kullanılan döndürme yöntemi olarak belirtilmektedir (Coşkun vd., 2017: 284). Faktör analizi sonucunda belirlenen faktörlerin güvenirliği önem arz etmektedir. Faktörlere güvenirlik analizi yapılarak Cronbach's Alpha değerleri belirlenmektedir. Bu değerin genel olarak en az 0,7 olması arzu edilmekte ancak bazı çalışmalarda bu değerin 0,5'e kadar kabul edildiği de görülmektedir (Çoşkun vd., 2017: 133).

Tablo 1'de destinasyon imajını oluşturan bilişsel imaj değişkeninin açıklayıcı faktör analizi sonucu yer almaktadır. Bulgular sonucunda 5 ifade binişik madde olduğu için analizden çıkarılmıştır. Bu ifadeler, "Bodrum iyi gece hayatına ve eğlenceye sahiptir", "Bodrum uygun konaklama yerlerine sahiptir", "Bodrum yöresel yemeklere (mutfak) sahiptir", "Bodrum harika plajlara ve su sporlarına sahiptir", "Bodrum ilginç ve dostça insanlara sahiptir" olarak sıralanabilir. Belirlenen ifadeler analizden çıkarılarak kalan 9 ifade için tekrar açıklayıcı faktör analizi yapılmış ve üç faktör ortaya çıkmıştır.

Tablo 1. Bilişsel İmaj Ölçeği Açıklayıcı Faktör Analizi Sonuçları

\begin{tabular}{|c|l|c|c|}
\hline \multirow{2}{*}{ Faktör } & \multicolumn{1}{|c|}{ Ifadeler } & $\begin{array}{c}\text { Faktör } \\
\text { Yükü }\end{array}$ & Değerler \\
\hline \multirow{2}{*}{ Deneyim Kalitesi } & Bodrum altyapı kalitesine sahiptir. &, 817 & Öz Değer: 2,044 \\
\cline { 2 - 4 } & Bodrum standart hijyen ve temizliğe sahiptir. &, 756 & Açılanan Varyans: 22,711 \\
\hline
\end{tabular}


Savaşçı U. \& Yıldırım, H. M. (2021). Impact of Destination Image and Perceived Risk on Behavioral Intention:

The Case of Bodrum. GSI Journals Serie A: Advancements in Tourism, Recreation and Sports Sciences (ATRSS), 4 (2): 17-36

\begin{tabular}{|c|c|c|c|}
\hline & Bodrum kişisel güvenliğe sahiptir. & ,724 & $\begin{array}{c}\text { Cronbach's Alpha: ,724 } \\
\text { Ortalama: } 3,83 \\
\end{array}$ \\
\hline \multirow{3}{*}{ Çekicilik } & Bodrum ilginç tarihi mekanlara sahiptir. & 886 & \multirow{3}{*}{$\begin{array}{c}\text { Öz Değer: 1,943 } \\
\text { Açılanan Varyans: } 21,591 \\
\text { Cronbach's Alpha: ,753 } \\
\text { Ortalama: 4,00 }\end{array}$} \\
\hline & Bodrum ilginç kültürel merkezlere sahiptir. & 831 & \\
\hline & $\begin{array}{l}\text { Bodrum güzel manzaralara ve doğal mekanlara } \\
\text { sahiptir. }\end{array}$ &, 547 & \\
\hline \multirow{3}{*}{ Değer ve Çevre } & Bodrum para için iyi bir değere sahiptir. & ,741 & \multirow{3}{*}{$\begin{array}{c}\text { Öz Değer: 1,767 } \\
\text { Açılanan Varyans: 19,638 } \\
\text { Cronbach's Alpha: ,607 } \\
\text { Ortalama: 4,09 }\end{array}$} \\
\hline & Bodrum iyi bir iklime sahiptir. & ,723 & \\
\hline & $\begin{array}{l}\text { Bodrum kirlenmemiş ve bozulmamış bir } \\
\text { çevreye sahiptir. }\end{array}$ & 615 & \\
\hline \multicolumn{2}{|r|}{ Açıklanan Varyans } & \multicolumn{2}{|r|}{63,941} \\
\hline \multicolumn{2}{|r|}{ Ölçek Cronbach's Alpha Değeri } & \multicolumn{2}{|r|}{800} \\
\hline \multicolumn{2}{|r|}{ KMO Örneklem Yeterliliği } & \multicolumn{2}{|r|}{,788 } \\
\hline \multicolumn{2}{|c|}{ Bartlett Küresellik Testi, Ki Kare / df / Sig. } & \multicolumn{2}{|r|}{$1113,745 / 36 /, 000$} \\
\hline
\end{tabular}

*Döndürme Yöntemi: Varimax Döndürme Yöntemi

Sonuçlar neticesinde üç faktörün toplam varyansın 63,941'ini açıkladığı ve alfa değerinin 0,800 olduğu görülmektedir. 3 ifadeden oluşan ilk faktörün öz değeri 2,044; varyansı açıklama oranı 22,711; alfa değeri 0,724; ortalama sonucu 3,83 olarak belirlenmiştir. İlk faktör Deneyim Kalitesi olarak isimlendirilmiştir. 3 ifadeden oluşan ikinci faktörün öz değeri 1,943; varyansı açıklama oranı 21,591; alfa değeri 0,753; ortalama sonucu 4,00 olarak belirlenmiştir. İkinci faktör Çekicilik olarak isimlendirilmiştir. Son olarak 3 ifadeden oluşan üçüncü faktörün öz değeri 1,767; varyansı açıklama oranı 19,638; alfa değeri 0,607; ortalama sonucu 4,09 olarak belirlenmiştir. Üçüncü faktör Değer ve Çevre olarak isimlendirilmiştir. Bilişsel imaj ölçeğinin KMO ve Bartlett testi değerlerinin, belirtilen şartları karşıladığı görülmektedir. Faktör isimlendirmeleri için ölçek kaynağından yararlanılmıştır. Bu doğrultuda faktörlerin literatür ile örtüştüğü söylenebilir.

Duygusal imaj 4'lü Semantik ölçek olarak 4 ifadeden oluşmaktadır. Destinasyon imajını oluşturan duygusal imaj değişkenine ait ortalama sonuçları değerlendirildiğinde. Bulgular sonucunda sıkıcı/heyecanlı değerinin ortalaması 3,28; çirkin/güzel değerinin ortalaması 3,33; uyuşuk/canlı değerinin ortalaması 3,13; sıkıntı verici/rahatlatıcı değerinin ortalaması 3,35 olarak bulunmuştur. Destinasyon imajını oluşturan genel imaj değişkenine ait ortalama sonucuna bakıldığında. Genel imaj 7'li Semantik ölçek olarak 1 ifadeden oluşmaktadır. Sonuçlar negatif/pozitif değerinin ortalamasının 5,44 olduğunu göstermektedir. Bu doğrultuda Bodrum destinasyonunun genel olarak pozitif imaja sahip olduğu söylenebilir.

Tablo 2.'de algılanan risk değişkenine ait açıklayıcı faktör analizi sonucu yer almaktadır. Bulgular sonucunda 1 ifade binişik madde olduğu için analizden çıkarılmıştır. Bu ifade ölçekteki 22. ifade olan "Bodrum otelleri hizmet kalitesi açısından tatmin edici değil" ifadesidir. Belirlenen ifade analizden çıkarılarak kalan 28 ifade için tekrar açıklayıcı faktör analizi yapılmış ve 4 faktör ortaya çıkmıştır.

Bulgular doğrultusunda dört faktörün toplam varyansın 69,507'sini açıkladığ 1 ve alfa değerinin 0,965 olduğu görülmektedir. 8 ifadeden oluşan ilk faktörün öz değeri 6,362; varyansı açıklama oranı 22,720; alfa değeri 0,952; ortalama sonucu 1,78 olarak belirlenmiştir. İlk faktör Sosyo-Psikolojik ve Zamansal Risk olarak isimlendirilmiştir. 8 ifadeden oluşan ikinci faktörün öz değeri 5,370; varyansı açıklama oranı 19,179; alfa değeri 0,920; ortalama sonucu 1,95 olarak belirlenmiştir. İkinci faktör Fiziksel Risk olarak isimlendirilmiştir. 7 ifadeden oluşan üçüncü faktörün öz değeri 4,720; varyansı açıklama oranı 15,249; alfa değeri 0,914; ortalama sonucu 1,95 olarak belirlenmiştir. Üçüncü faktör Performans Riski olarak isimlendirilmiştir. 5 ifadeden oluşan dördüncü ve son faktörün öz değeri 3,461; varyansı açıklama oranı 12,359; alfa değeri 0,851; ortalama sonucu 2,17 olarak belirlenmiştir. Dördüncü faktör Finansal Risk olarak isimlendirilmiştir. Algılanan risk ölçeğinin $\mathrm{KMO}$ ve Bartlett değerlerinin, belirtilen şartları karşıladığ1 görülmektedir. 
Savaşçı U. \& Yıldırım, H. M. (2021). Impact of Destination Image and Perceived Risk on Behavioral Intention:

The Case of Bodrum. GSI Journals Serie A: Advancements in Tourism, Recreation and Sports Sciences (ATRSS), 4 (2): 17-36

Tablo 2. Algılanan Risk Ölçeği Açıklayıcı Faktör Analizi Sonuçları

\begin{tabular}{|c|c|c|c|}
\hline Faktör & İfadeler & $\begin{array}{l}\text { Faktör } \\
\text { Yükü }\end{array}$ & Değerler \\
\hline \multirow{8}{*}{ 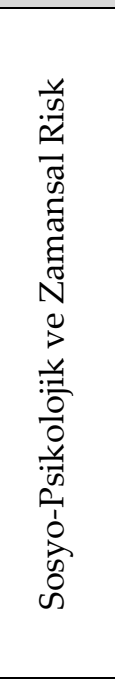 } & $\begin{array}{l}\text { Bodrum'daki tatilimin ailemin benimle ilgili düşüncelerini } \\
\text { değiştireceğinden endişeliyim. }\end{array}$ & ,855 & \multirow{8}{*}{$\begin{array}{l}\text { Öz Değer: 6,362 } \\
\text { Açıklanan Varyans: } 22,720 \\
\text { Cronbach's Alpha: }, 952 \\
\text { Ortalama: } 1,78\end{array}$} \\
\hline & $\begin{array}{l}\text { Bodrum'daki tatilimin arkadaşlarımın benimle ilgili } \\
\text { düşüncelerini değiştireceğinden endişeliyim. }\end{array}$ & 824 & \\
\hline & Tatilin zaman kaybı olduğunu düşünüyorum. & ,793 & \\
\hline & $\begin{array}{l}\text { Genel olarak Bodrum tatilimin zaman kaybı olduğunu } \\
\text { düşünüyorum. }\end{array}$ & 793 & \\
\hline & $\begin{array}{l}\text { Bodrum tatil planımın ve programımın zaman kaybı olduğunu } \\
\text { düşünüyorum. }\end{array}$ & ,786 & \\
\hline & $\begin{array}{l}\text { Bodrum seyahatimin hayattaki (sosyal sınıf) durumumla } \\
\text { eşleşmeyeceğinden endişeliyim. }\end{array}$ & 763 & \\
\hline & $\begin{array}{l}\text { Bodrum'daki tatilden kişisel memnuniyet alamayacağım için } \\
\text { endişeliyim. }\end{array}$ & ,746 & \\
\hline & Bodrum tatili kişiliğime uygun değil. & 569 & \\
\hline \multirow{8}{*}{ 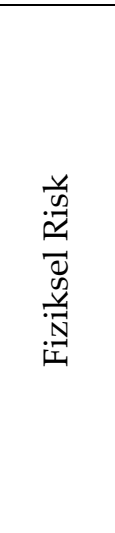 } & Bodrum'da siyasi huzursuzluk var. & 801 & \multirow{8}{*}{$\begin{array}{l}\text { Öz Değer: 5,370 } \\
\text { Açıklanan Varyans: } 19,179 \\
\text { Cronbach's Alpha: }, 920 \\
\text { Ortalama: } 1,95\end{array}$} \\
\hline & Bodrum'da hirsızlık ve kapkaç var. & 763 & \\
\hline & Bodrum'da terör eylemleri var. & ,723 & \\
\hline & Bodrum'da doğal afetler (deprem, sel ve fırtına vb.) var. & ,717 & \\
\hline & Bodrum'da bulaşıcı hastalıklar (H1N2 Grip, HIV vb.) var. & 682 & \\
\hline & $\begin{array}{l}\text { Bodrum'da bir trafik kazasında yaralanmaktan endişe } \\
\text { duyuyorum. }\end{array}$ & 667 & \\
\hline & $\begin{array}{l}\text { Davranışımın bazı Bodrumlular tarafından iyi } \\
\text { karşılanmayacağından endişeliyim (geleneksel giyim tarzı } \\
\text { dahil). }\end{array}$ &, 562 & \\
\hline & Bodrum'da yiyecek ve içecek güvenliği sorunları var. & 553 & \\
\hline \multirow{7}{*}{ 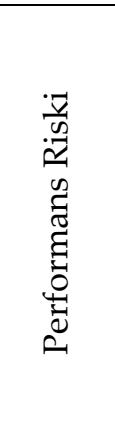 } & Bodrum'daki insanlar dostça değil. & ,747 & \multirow{7}{*}{$\begin{array}{l}\text { Öz Değer: } 4,720 \\
\text { Açıklanan Varyans: } 15,249 \\
\text { Cronbach's Alpha: }, 914 \\
\text { Ortalama: } 1,95\end{array}$} \\
\hline & Bodrum otellerindeki personel kibar değil. & ,724 & \\
\hline & Bodrum'da yemeklerin iyi olmayacağından endişeliyim. & 673 & \\
\hline & Havanın kötü olmasından endişeliyim. & 660 & \\
\hline & $\begin{array}{l}\text { Bodrum'da halka açı olan turistik tesislerin kabul } \\
\text { edilemeyeceğinden endişeliyim. }\end{array}$ & 613 & \\
\hline & Alanların çok kalabalık olacağından endişeliyim. & ,566 & \\
\hline & $\begin{array}{l}\text { Bodrum'da olası grevlerden (havaalanı, tren istasyonu, } \\
\text { otobüsler) endişeliyim. }\end{array}$ &, 520 & \\
\hline \multirow{5}{*}{ 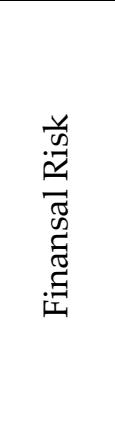 } & Bodrum'daki tatil ülkemdeki herhangi bir tatilden daha pahalı. & 779 & \multirow{5}{*}{$\begin{array}{l}\text { Öz Değer: } 3,461 \\
\text { Açılanan Varyans: } 12,359 \\
\text { Cronbach's Alpha: ,851 } \\
\text { Ortalama: } 2,17\end{array}$} \\
\hline & Bodrum'daki tatil bütçem için çok pahalı. & 701 & \\
\hline & $\begin{array}{l}\text { Bodrum tatilim boyunca fazladan harcamalar (fazladan otel } \\
\text { harcamaları vb.) var. }\end{array}$ & 675 & \\
\hline & $\begin{array}{l}\text { Bodrum gezisinin giyim, haritalar, spor malzemeleri, bebek } \\
\text { bakıcısı gibi beklediğimden daha fazla harcama } \\
\text { gerektireceğinden endişeliyim. }\end{array}$ & 663 & \\
\hline & $\begin{array}{l}\text { Tatil için ödediğim tutar için yeterli hizmet aldığımı } \\
\text { düşünmüyorum. }\end{array}$ &, 549 & \\
\hline \multicolumn{2}{|r|}{ Açılanan Varyans } & \multicolumn{2}{|r|}{69,507} \\
\hline \multirow{2}{*}{\multicolumn{2}{|c|}{$\begin{array}{l}\text { Ölçek Cronbach's Alpha Değeri } \\
\text { KMO Örneklem Yeterliliği }\end{array}$}} & \multicolumn{2}{|r|}{,965 } \\
\hline & & & ,959 \\
\hline \multicolumn{2}{|r|}{ Bartlett's Küresellik Testi, Ki Kare / df / Sig. } & \multicolumn{2}{|r|}{$11404,192 / 378 /, 000$} \\
\hline
\end{tabular}

*Döndürme Yöntemi: Varimax Döndürme Yöntemi

Faktör isimlendirmelerinde ölçek kaynağından yararlanılmıştır ve faktörlerin literatür ile örtüştüğü söylenebilir. Fuchs ve Reichel (2006) çalışmalarında algılanan riski 5 faktör olarak belirlemişlerdir. Bu 
faktörler; sosyo-psikolojik risk, zaman riski, fiziksel risk, finansal risk, performans riski olarak siralanabilir. Bu faktörlere ek olarak algılanan genel risk adı altında 1 ek faktör oluşturmuşlardır. Bu çalışmada ise araştırma bulguları sonucunda sosyo-psikolojik risk ve zaman riski faktörleri birleşmiş bu doğrultuda "sosyo-psikolojik ve zamansal risk" faktörü oluşturulmuştur. Çalışmada algılanan risk ölçeği, 4 faktörden oluşmuş ve ek olarak genel risk algısı da değerlendirilmiştir. Algılanan genel risk 5'li Likert ölçek olarak 1 ifadeden oluşmaktadır. Algılanan genel risk ölçeğine ait ortalama sonucuna göre ifade değerinin ortalamasının 4,09 olduğu belirlenmiştir. Bu doğrultuda Bodrum destinasyonunun genel olarak güvenli destinasyon algısına sahip olduğu söylenebilir.

Tablo 3'te davranışsal niyet değişkeninin açıklayıcı faktör analizi sonucu yer almaktadır. Bulgular sonucunda üç faktör ortaya çıkmıştır. Oluşan faktörün toplam varyansın 66,870'ini açıkladığ1 ve alfa değerinin 0,870 olduğu görülmektedir. 5 ifadeden oluşan faktörün öz değeri 3,343; varyansı açıklama oranı 66,870; alfa değeri 0,870; ortalama sonucu 3,76 olarak belirlenmiştir. Faktör Sadakat olarak isimlendirilmiştir. Davranışsal niyet ölçeğinin $\mathrm{KMO}$ ve Bartlett değerlerinin, belirtilen şartları karşıladığ1 görülmektedir. Faktör isimlendirmelerinde ölçek kaynağından yararlanılmıştır ve faktörün literatür ile örtüştüğü söylenebilir.

Tablo 3. Davranışsal Niyet Ölçeği Açıklayıcı Faktör Analizi Sonuçları

\begin{tabular}{|c|c|c|c|}
\hline Faktör & İfadeler & $\begin{array}{l}\text { Faktör } \\
\text { Yükü }\end{array}$ & Değerler \\
\hline \multirow{5}{*}{ Sadakat } & $\begin{array}{l}\text { Bodrum'u tavsiyemi isteyen birisine tatil için } \\
\text { tavsiye ederim. }\end{array}$ & 877 & \multirow{5}{*}{$\begin{array}{c}\text { Öz Değer: } 3,343 \\
\text { Açılanan Varyans: } 66,870 \\
\text { Cronbach's Alpha: }, 870 \\
\text { Ortalama: } 3,76\end{array}$} \\
\hline & $\begin{array}{l}\text { Etrafımdaki insanları Bodrum'a gelmeye teşvik } \\
\text { ederim. }\end{array}$ & 873 & \\
\hline & $\begin{array}{l}\text { Bodrum hakkında diğer insanlara olumlu şeyler } \\
\text { söylerim. }\end{array}$ & ,845 & \\
\hline & $\begin{array}{l}\text { Bodrum'u bir sonraki tatilim için ilk tercihim } \\
\text { olarak görüyorum. }\end{array}$ & ,758 & \\
\hline & $\begin{array}{l}\text { Önümüzdeki birkaç yıl içinde Bodrum'u daha sık } \\
\text { ziyaret edeceğim. }\end{array}$ & ,725 & \\
\hline \multicolumn{2}{|r|}{ Açıklanan Varyans } & \multicolumn{2}{|r|}{66,870} \\
\hline \multicolumn{2}{|r|}{ Ölçek Cronbach's Alpha Değeri } & \multicolumn{2}{|r|}{870} \\
\hline \multicolumn{2}{|c|}{ KMO Örneklem Yeterliliği } & \multicolumn{2}{|r|}{,794 } \\
\hline \multicolumn{2}{|c|}{ Bartlett's Küresellik Testi, Ki Kare / df / Sig. } & \multicolumn{2}{|r|}{$1406,445 / 10 /, 000$} \\
\hline
\end{tabular}

*Döndürme Yöntemi: Varimax Döndürme Yöntemi

\subsection{Doğrulayıcı Faktör Analizi (DFA) Bulguları}

Doğrulayıcı faktör denklemlerinin belirlenmesinde "Maksimum Benzerlik Tahmini (Maximum Likelihood Estimation)" yöntemi kullanılır. Hair ve arkadaşlarına (2014) göre bir ifadenin faktörü açılayabilmesi için 0,50 ile 0,99 arasında değere sahip olması ve değişkene ait $t$ değerinin 1,96'nın üzerinde olması gerekmektedir. Modellerin sınanmasında genellikle Ki-kare uyum testi (x2), yaklaşık hata kareler ortalaması karekökü (RMSEA), uyum iyiliği indeksi (GFI), karşılaştırmalı uyum indeksi (CFI) sonuçları önem arz etmektedir. Ki-kare değeri, belirtilen modelin kovaryans matrisi ile örneklem kovaryans matrisi arasında fark olup olmadığını göstermektedir. Bu değer örneklem hacmine bağlı olarak değişmekte ve serbestlik derecesi ile birlikte değerlendirilmektedir. Değerin, iyi uyum gösteren modellerde 0 ile 2 arasında olduğu, kabul edilebilir modellerde ise 2 ile 5 arasında olduğu kabul edilmektedir. Modelin uyumunu gösteren bir diğer indeks olan, yaklaşık hata kareler ortalaması karekökü "RMSEA" örneklem hacminden kaynaklanan hataların önüne geçilmesi amaciyla güven aralığ1 sağlamaktadır. Bu değerin 0 ile 0,05 aralığında olması iyi uyumu; 0,05 ile 0,08 aralığında olması kabul edilebilir uyumu göstermektedir. Uyum iyiliği indeksi "GFI" model tarafından açıklanan varyans ve kovaryans miktarının bir değeridir. GFI değerinin 0,95 ile 1,00 arasında olması iyi uyumu; 0,90 ile 0,95 arasında olması kabul edilebilir uyumu gösterir. Karşılaştırmalı uyum indeksi "CFI" en çok kullanılan 
değerdir. Bu değerin de iyi uyum için 0,97 ile 1,00 arasında olması, kabul edilebilir uyum için 0,90 ile 0,97 arasında olması gerekmektedir (Bayram, 2010: 69-79; Meydan ve Şeşen, 2015).

Doğrulayıcı faktör analizinde, modelin uyum iyiliğine bakıldıktan sonra yapısal geçerliliğine de bakılması gerekmektedir. Yapısal geçerliliğin tespiti için ilk olarak yakınsak ve ıraksak (ayırt edici) geçerliliklere bakılmalıdır. Yakınsak geçerliliğin tespiti için modeli oluşturan faktörlerin ortalama varyans değerleri (AVE) ve bileşik güvenirlik katsayıları (CR) hesaplanmalıdır. Fornell ve Larcker (1981) çalışmalarında “CR" değerinin 0,70'den yüksek; “AVE" değerinin 0,50'den yüksek olması gerektiğini belirtmişlerdir. Ayrıca "CR" değerinin 0,60 ve 0,70 aralığında olması durumunda kabul edilebilir olduğunu belirten çalışmalar bulunmaktadır (Hair vd., 2016: 112). “AVE" değerinin 0,50'nin altında olduğu durumlarda ise diğer güvenirlik değerlerinin uygun düzeyde bulunması şartıyla kabul edilebilir olduğu belirtilmektedir (Berthon vd., 2005: 164). Bu açıklamalara ek olarak Hair ve arkadaşları (2016) CR değerinin AVE değerinden büyük olması gerektiğini belirtmişlerdir. Değerlerin belirlenmesinin ardından ayrışma geçerliliğinin sağlanması gerekmektedir. Ayrışma geçerliliği için iki yaklaşım uygulanmaktadır. İlk yaklaşım faktörler arası korelasyon değerlerine bakılmasıdır. Kline (1998) korelasyon değerlerinin 0,85'den küçük olması durumunda ayrışma geçerliliğinin sağlandığını belirtmektedir. İkinci yaklaşım ise Fornell ve Larcker'e (1981) göre bir faktöre ait ortalama açıklanan varyans (AVE) değerinin, faktörler arasındaki en büyük korelasyon değerinin karesinden büyük olmasıdır. Yapısal geçerlilik için hem yakınsak hem de ayrışma geçerliliklerinin sağlanması durumunda modelin kabul edilebilir olduğuna karar verilmektedir.

Araştırma kapsamında ilk olarak bilişsel imaj ölçeğine doğrulayıcı faktör analizi yapılmıştır. Yapılan analiz sonucunda ortaya çıkan sonuçlar modelin uygun olduğunu göstermektedir. Bulgulara göre "Kikare / serbestlik derecesi: 3,585”, “RMSEA: 0,075”, “GFI: 0,961”, “CFI: 0,946” olarak belirlenmiştir. Uyum iyiliği değerlerinin, değerlendirilmesinin ardından yapısal geçerliliğin tespiti için AVE (ortalama varyans) ve CR (bileşik güvenirlik) değerleri hesaplanmıştır. Ortaya çıkan sonuçlar Tablo 4.'de sunulmaktadır. Sonuçlara göre standardize yüklerin 0,50'nin üzerinde olduğu görülmektedir. Birinci değişken olan “Deneyim Kalitesi” değişkeninin AVE değeri 0,47; CR değeri 0,73 olarak belirlenmiştir. Değişkene ait AVE değerinin eşik değer olan 0,50'nin altında olduğu ancak CR değerinin eşik değer olan 0,60'ın üstünde olduğu görülmektedir. İkinci değişken olan “Çekicilik” değişkeninin AVE değeri 0,59; CR değeri 0,80 olarak belirlenmiştir. Değişkene ait hem AVE hem de CR değerleri eşik değerlerin üzerindedir. Üçüncü değişken olan "Değer ve Çevre" değişkeninin AVE değeri 0,35; CR değeri 0,62 olarak belirlenmiştir. Değişkene ait AVE değerinin eşik değer olan 0,50'nin altında olduğu ancak CR değerinin eşik değer olan 0,60'in üstünde olduğu görülmektedir. Ayrıca belirlenen CR değerleri, AVE değerlerinden büyük değerlere sahiptir.

Tablo 4. Bilişsel İmaj Ölçeği Doğrulayıcı Faktör Analizi Sonuçları

\begin{tabular}{|c|c|c|c|c|c|}
\hline Değişkenler & İfadeler & $\begin{array}{c}\text { Standardize } \\
\text { Yükler }\end{array}$ & $\begin{array}{l}\text { Ölçüm Hata } \\
\text { Değerleri }\end{array}$ & AVE & CR \\
\hline \multirow{3}{*}{ Deneyim Kalitesi } & İmaj 1 & ,649 &, 578 & \multirow{3}{*}{0,47} & \multirow{3}{*}{0,73} \\
\hline & İmaj 2 & ,723 & ,477 & & \\
\hline & İmaj 3 & 682 &, 543 & & \\
\hline \multirow{3}{*}{ Çekicilik } & İmaj 9 & 855 & ,268 & \multirow{3}{*}{0,59} & \multirow{3}{*}{0,80} \\
\hline & İmaj 10 & ,761 & 420 & & \\
\hline & İmaj 11 & 661 &, 563 & & \\
\hline \multirow{3}{*}{ Değer ve Çevre } & İmaj 12 &, 557 & ,689 & \multirow{3}{*}{0,35} & \multirow{3}{*}{0,62} \\
\hline & İmaj 13 &, 593 & ,648 & & \\
\hline & İmaj 14 & ,613 & ,624 & & \\
\hline
\end{tabular}

Yapısal geçerlilik için boyutların ayrışma geçerliliğine bakılmıştır. Modelin ayrışma geçerliliğinin sınanmasında korelasyon analizinden yararlanılmıştır ve sonuçlar Tablo 5.'de sunulmaktadır. Bulgulara göre deneyim kalitesi değişkenine ait en yüksek korelasyon değeri “0,441" olarak; çekicilik değişkenine ait en yüksek korelasyon değeri “ 0,447 ” olarak; değer ve çevre değişkenine ait en yüksek korelasyon 
değeri de "0,447" olarak belirlenmiştir. Bulgular değerlerin eşik değer olan 0,85'in altında olduğunu göstermektedir. Ayrıca faktörler arasındaki en yüksek korelasyon değerlerinin karelerinin, değişkenlere ait AVE değerlerinden küçük olduğu görülmektedir. Sonuçlar neticesinde "Bilişsel İmaj" ölçeğinin istenilen şartları sağladığı ve ölçek modelinin uygun olduğu belirlenmiştir.

Tablo 5. Bilişsel İmaj Ölçeği Korelasyon ve Geçerlilik Sonuçları

\begin{tabular}{|c|c|c|c|c|}
\hline Değişkenler & Deneyim Kalitesi & Çekicilik & Değer ve Çevre & {$[<$ AVE] } \\
\hline Deneyim Kalitesi & 1 & - & - & 0,194 \\
\hline Çekicilik &, $385^{* *}$ & 1 & - & 0,199 \\
\hline Değer ve Çevre &, $441^{* *}$ &, $447^{* *}$ & 1 & 0,199 \\
\hline
\end{tabular}

Araştırma kapsamında algılanan risk ölçeğine doğrulayıcı faktör analizi yapılmıştır. Yapılan analiz sonucunda ortaya çıkan sonuçlar modelin uygun olduğunu göstermektedir. Bulgulara göre "Ki-kare / serbestlik derecesi: 2,243”, “RMSEA: 0,052”, “GFI: 0,901”, “CFI: 0,965” olarak belirlenmiştir. Yapisal geçerlilik için ilk olarak AVE (ortalama varyans) ve CR (bileşik güvenirlik) değerleri hesaplanmıştır. Ortaya çıkan sonuçlar Tablo 6.'da sunulmaktadır. Sonuçlara göre standardize yüklerin 0,50'nin üzerinde olduğu görülmektedir. Birinci değişken olan "Sosyo-Psikolojik ve Zamansal Risk" değişkeninin AVE değeri 0,70; CR değeri 0,95 olarak belirlenmiştir. İkinci değişken olan "Fiziksel Risk" değişkeninin AVE değeri 0,58; CR değeri 0,92 olarak belirlenmiştir. Üçüncü değişken olan "Finansal Risk" değişkeninin AVE değeri 0,52 ; CR değeri 0,85 olarak belirlenmiştir. Dördüncü değişken olan "Performans Riski" değişkeninin AVE değeri 0,59; CR değeri 0,90 olarak belirlenmiştir. Değişkenlere ait AVE değerlerinin eşik değer olan 0,50'nin üstünde olduğu; CR değerlerinin eşik değer olan 0,60'ın üstünde olduğu görülmektedir. Ayrıca belirlenen CR değerleri, AVE değerlerinden büyük değerlere sahiptir.

Tablo 6. Algılanan Risk Ölçeğinin Doğrulayıcı Faktör Analizi Sonuçları

\begin{tabular}{|c|c|c|c|c|c|}
\hline Değişkenler & İfadeler & $\begin{array}{c}\text { Standardize } \\
\text { Yükler }\end{array}$ & $\begin{array}{c}\text { Ölçüm Hata } \\
\text { Değerleri }\end{array}$ & AVE & CR \\
\hline \multirow{8}{*}{$\begin{array}{l}\text { Sosyo-Psikolojik } \\
\text { ve Zamansal Risk }\end{array}$} & Risk 1 & ,632 & ,600 & \multirow{8}{*}{0,70} & \multirow{8}{*}{0,95} \\
\hline & Risk 2 & 824 & ,321 & & \\
\hline & Risk 3 & ,866 & ,250 & & \\
\hline & Risk 4 & ,914 & ,164 & & \\
\hline & Risk 5 & 890 & ,200 & & \\
\hline & Risk 6 & ,839 & ,296 & & \\
\hline & Risk 7 & ,844 & ,287 & & \\
\hline & Risk 8 & 827 & ,316 & & \\
\hline \multirow{8}{*}{ Fiziksel Risk } & Risk 9 & ,828 & ,314 & \multirow{8}{*}{0,58} & \multirow{8}{*}{0,92} \\
\hline & Risk 10 & 821 & ,325 & & \\
\hline & Risk 11 & ,798 & ,363 & & \\
\hline & Risk 12 & 821 & ,325 & & \\
\hline & Risk 13 & ,777 & ,396 & & \\
\hline & Risk 14 & ,750 & ,430 & & \\
\hline & Risk 15 &, 550 & ,690 & & \\
\hline & Risk 16 & 695 & ,516 & & \\
\hline \multirow{5}{*}{ Finansal Risk } & Risk 17 & ,780 & ,390 & \multirow{5}{*}{0,52} & \multirow{5}{*}{0,85} \\
\hline & Risk 18 & ,672 &, 548 & & \\
\hline & Risk 19 & 637 & ,594 & & \\
\hline & Risk 20 & ,731 & ,465 & & \\
\hline & Risk 21 & ,754 & ,431 & & \\
\hline \multirow{5}{*}{ Performans Riski } & Risk 23 & ,727 & 471 & \multirow{5}{*}{0,59} & \multirow{5}{*}{0,90} \\
\hline & Risk 24 & ,732 &, 464 & & \\
\hline & Risk 25 & 837 & ,299 & & \\
\hline & Risk 26 & ,698 &, 512 & & \\
\hline & Risk 27 & ,787 & ,380 & & \\
\hline
\end{tabular}




\begin{tabular}{|l|l|l|l|l|l|}
\hline & Risk 28 &, 776 &, 397 & \\
\cline { 2 - 4 } & Risk 29 &, 803 &, 355 & \\
\hline
\end{tabular}

Yapısal geçerlilik için boyutların ayrışma geçerliliğine de bakılmıştır. Modelin ayrışma geçerliliğinin sınanmasında korelasyon analizinden yararlanılmıştır ve sonuçlar Tablo 7.'de sunulmaktadır. Bulgulara göre sosyo-psikolojik ve zamansal risk değişkenine ait en yüksek korelasyon değeri “0,690” olarak; fiziksel risk değişkenine ait en yüksek korelasyon değeri “0,757" olarak; finansal risk değişkenine ait en yüksek korelasyon değeri “0,708” olarak; performans riski değişkenine ait en yüksek korelasyon değeri “0,757" olarak belirlenmiştir. Bulgular değerlerin eşik değer olan 0,85'in altında olduğunu göstermektedir. Ayrıca faktörler arasındaki en yüksek korelasyon değerlerinin karelerinin, değişkenlere ait AVE değerlerinden küçük olduğu görülmektedir. Sonuçlar neticesinde "Algılanan Risk" ölçeğinin istenilen şartları sağladığ ve ölçek modelinin uygun olduğu belirlenmiştir.

Tablo 7. Algılanan Risk Ölçeği Korelasyon ve Geçerlilik Sonuçları

\begin{tabular}{|c|c|c|c|c|c|}
\hline Değişkenler & $\begin{array}{c}\text { Sosyo-Psikolojik ve } \\
\text { Zamansal Risk }\end{array}$ & $\begin{array}{c}\text { Fiziksel } \\
\text { Risk }\end{array}$ & $\begin{array}{c}\text { Finansal } \\
\text { Risk }\end{array}$ & $\begin{array}{c}\text { Performans } \\
\text { Riski }\end{array}$ & {$[<$ AVE] } \\
\hline Sosyo-Psikolojik ve Zamansal Risk & 1 & - & - & - & 0,476 \\
\hline Fiziksel Risk &, $675^{* *}$ & 1 & - & - & 0,573 \\
\hline Finansal Risk &, $618^{* *}$ &, $639^{* *}$ & 1 & - & 0,501 \\
\hline Performans Riski &, $690^{* *}$ &, $757^{* *}$ &, $708^{* *}$ & 1 & 0,573 \\
\hline
\end{tabular}

Araştırma kapsamında üçüncü değişkene yönelik olarak davranışsal niyet ölçeğine doğrulayıcı faktör analizi yapılmıştır. Yapılan analiz sonucunda ortaya çıkan sonuçlar modelin uygun olduğunu göstermektedir. Bulgulara göre “Ki-kare / serbestlik derecesi: 3,179”, “RMSEA: 0,069”, “GFI: 0,992”, “CFI: 0,995" olarak belirlenmiştir. Uyum iyiliği değerlerinin, değerlendirilmesinin ardından yapısal geçerliliğe bakılmıştır. Ortaya çıkan sonuçlar Tablo 8.'de sunulmaktadır. Sonuçlara göre standardize yüklerin 0,50'nin üzerinde olduğu görülmektedir. Davranışsal niyet ölçeği tek değişkenden oluşmaktadır ve "Sadakat" değişkenine ait AVE değeri 0,58; CR değeri 0,87 olarak belirlenmiştir. Değişkenin AVE değerinin eşik değer olan 0,50'nin; CR değerinin eşik değer olan 0,60'ın üstünde olduğu görülmektedir. Ayrıca CR değeri, AVE değerinden büyük değere sahiptir. Model tek değişkenden oluştuğu için ayrışma geçerliliğine bakılamamıştır. Sonuçlar “Davranışsal Niyet” ölçeğinin istenilen şartları sağladığını ve uygun olduğunu göstermektedir.

Tablo 8. Davranışsal Niyet Ölçeği Doğrulayıcı Faktör Analizi Sonuçları

\begin{tabular}{|c|c|c|c|c|c|}
\hline Değişkenler & İfadeler & $\begin{array}{c}\text { Standardize } \\
\text { Yükler }\end{array}$ & $\begin{array}{l}\text { Ölçüm Hata } \\
\text { Değerleri }\end{array}$ & AVE & CR \\
\hline \multirow{5}{*}{ Sadakat } & Sadakat 1 &, 848 &, 280 & \multirow{5}{*}{0,58} & \multirow{5}{*}{0,87} \\
\hline & Sadakat 2 & ,933 & ,129 & & \\
\hline & Sadakat 3 & 848 & ,280 & & \\
\hline & Sadakat 4 & ,537 & 711 & & \\
\hline & Sadakat 5 & ,508 & ,741 & & \\
\hline
\end{tabular}

\subsection{Hipotez Testleri Sonuçları}

Hipotez testlerinde ilk olarak araştırma modelinin test edilmesi için "Yapısal Eşitlik Modeli" yapılmıştır. Yapısal Eşitlik Modeli (YEM); faktör analizi, korelasyon ve çoklu regresyon gibi farklı istatistiksel yöntemlerin bir birleşimidir (İlhan ve Çetin, 2014: 28). Araştırma kapsamındaki yol analizleri ile elde edilen sonuçlar Şekil 1.' de gösterilmiş ve hipotez testleri açıklanmıştır. 


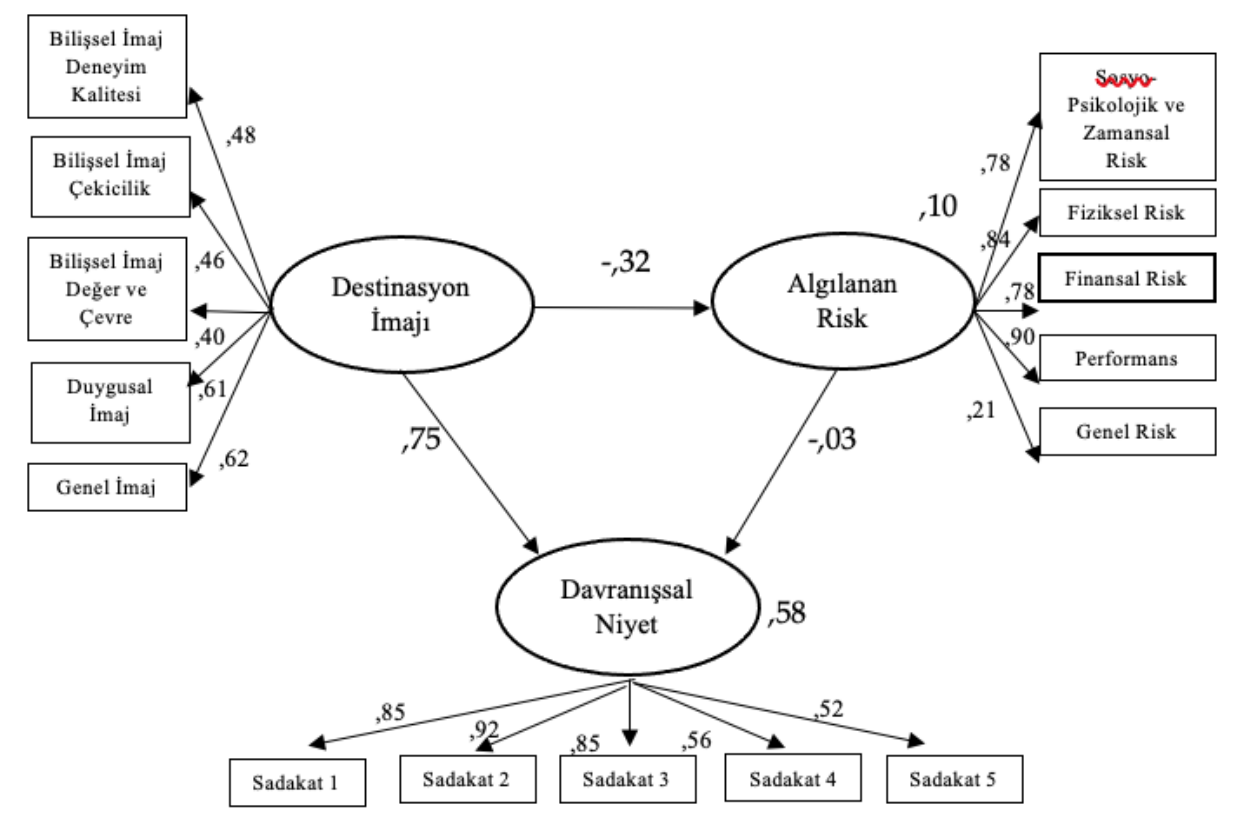

Şekil 2. Araştırma Modeline Yönelik Yapısal Eşitlik Modeli Sonuçları

Araştırmanın kavramsal modelinin testi sonucunda elde edilen uyum iyiliği değerleri, sonuçların kabul edilebilir eşik değerler aralığında olduğunu göstermektedir. Bu doğrultuda modelin yeterli uyum değerlerine sahip olduğu söylenebilir. Bulgulara göre "Ki-kare / serbestlik derecesi: 3,387", "RMSEA: 0,072”, “GFI: 0,922”, “CFI: 0,939” olarak belirlenmiştir.

Kavramsal modele ilişkin değişkenler arasında kurulan hipotezleri test etmek için yapılan yol analizi sonuçları Tablo 9.'da sunulmuştur. Sonuçlara göre "Destinasyon İmaj” ile "Algılanan Risk" arasında negatif yönlü ve anlamlı bir etki görülmüştür. Bu kapsamda H1 hipotezi desteklenmiştir. Araştırmanın ikinci hipotezine istinaden "Destinasyon İmajı” ile "Davranışsal Niyet" arasında pozitif yönlü ve anlamlı bir etki belirlenmiştir. Bu doğrultuda $\mathrm{H} 2$ hipotezi desteklenmiştir. Üçüncü araştırma hipotezine bakıldığında ise "Algılanan Risk" ile "Davranışsal Niyet" arasında negatif yönlü ancak istatistiksel açıdan anlamsız bir etki görülmüştür. Bu durumda H3 hipotezi desteklenmemiştir. Tabloda değişkenlere ait açıklanan varyans değerleri de görülmektedir.

Tablo 9. Yapısal Eşitlik Modeli Yol Analizi Sonuçları

\begin{tabular}{|c|c|c|}
\hline Yol & B & $\mathbf{R}^{\mathbf{2}}$ \\
\hline Destinasyon İmajı $\rightarrow$ Algılanan Risk &,$- 315\left(^{* * *}\right)$ & \\
\hline Destinasyon İmajı $\rightarrow$ Davranıssal Niyet &, $752\left(^{* * *}\right)$ & \\
\hline Algılanan Risk $\rightarrow$ Davranışsal Niyet &,- 029 & \\
\hline Algılanan Risk & &, 10 \\
\hline Davranışsal Niyet & &, 58 \\
\hline
\end{tabular}

$\left.{ }^{* * *}\right) \mathrm{p}<0,001$

\section{Sonuç ve Öneriler}

Turizm literatüründe yapılan çalışmalara bakıldığında destinasyon imajı, algılanan risk ve davranışsal niyet konularının önemli bir yere sahip olduğu ancak bu konuların birlikte araştırıldığı çalışmaların sınırlı sayıda bulunduğu görülmektedir. Bu doğrultuda araştırmada popüler bir turistik destinasyon olan Bodrum destinasyonunu ziyaret eden yabancı turistlerin, algıladıkları destinasyon imajinın ve destinasyon riskinin belirlenmesi ile davranışsal niyet üzerindeki etkilerinin ortaya çıkarılması amaçlanmıştır. Literatürdeki çalışmalar, destinasyon imajı, algılanan risk ve davranışsal niyet değişkenlerinin birbirleri ile ilişkili olduklarını göstermektedir. 
Hipotez testlerinde ilk olarak yapısal eşitlik modelinden yararlanılmış ve bulgular doğrultusunda, çalışma kapsamında kurulan birinci araştırma hipotezi desteklenmiştir. Araştırmanın birinci hipotezinin desteklenmesi destinasyon imajının, algılanan riski etkilediğini göstermektedir ve literatürdeki diğer çalışmalar ile örtüşmektedir (Chapius vd., 2015; Biswakarma, 2017; Makhdoomi ve Baba, 2019). Araştırma sonuçlarının benzer olduğu çalışmalardan birisi de Ateşoğlu ve Türker'in çalışmasıdır. Ateşoğlu ve Türker (2014) çalışmalarında Antalya, İstanbul, Muğla ve Kapadokya'yı ziyaret eden yabancı turistlerin destinasyon tercihinde, ülke imajının algılanan risklere etkisini belirlemeyi amaçlamışlardır. Sonuçlara göre ülke imajı ile algılanan risk arasında negatif yönlü bir ilişkinin olduğu belirlenmiştir. Çalışma kapsamında kurulan araştırmanın ikinci hipotezinin desteklenmesi destinasyon imajının, davranışsal niyeti etkilediğini göstermektedir. Elde edilen bu sonuç literatürdeki çalışmalar ile örtüşmektedir (Bigne vd., 2001; Chen ve Tsai, 2007; Atılgan İnan vd., 2011; Sevim vd., 2013; Şimşek ve Özdamar, 2020). Araştırma sonuçlarının benzer olduğu çalışmalardan birisi olan Zhang ve arkadaşlarının (2014) çalışmalarında destinasyon imajı ve turist sadakati arasındaki ilişki incelenmiş ve imajın, sadakati etkileyen önemli bir etken olduğu sonucu ortaya çıkmıştır. Çalışma kapsamında kurulan üçüncü araştırma hipotezi ise desteklenmemiştir. Üçüncü hipotezin desteklenmemesi algılanan riskin, davranışsal niyet üzerinde bir etkisinin olmadığını göstermektedir.

Araştırma sonuçlarına göre destinasyon imajının hem algılanan risk hem de davranışsal niyet üzerinde etkiye sahip olduğu belirlenmiştir. Bu doğrultuda bir destinasyonun turistler açısından tercih edilmesinde ve turizm açısından sürdürülebilirliğin sağlanmasında olumlu destinasyon imajının oluşturulması gerektiği söylenebilir. Bu çerçevede araştırma kapsamında özel sektöre, kamu kurumlarına ve araştırmacılara yönelik önerilerde bulunulmuştur.

- Araştırma bulgularına istinaden "finansal risk" boyutunun ortalama sonucu diğer risk faktörlerine göre daha yüksek belirlenmiştir. Bu doğrultuda Bodrum destinasyonu için işletmeler açısından fiyat-hizmet dengesinin iyi kurulması gerektiği tavsiye edilebilir. 2020 yılında yaşanan pandemi dönemi göz önüne alındığında ise turistlerin fiziksel risk algısının daha fazla olabileceği söylenebilir. Sağlık açısından algılanan risklerin azaltılması için işletmelerin gerekli tedbirleri almaları ve gerekli kriterleri sağlamaları gerekmektedir. Bu kapsamda Bodrum destinasyonu için işletmeler açısından Dünya Sağlık Örgütü'nün ve Türkiye Cumhuriyeti Sağlık Bakanlı̆̆ı' nın belirlediği hijyen ve kişisel güvenlik kurallarına uygun tedbirlerin alınması ve tedbirlerin uygulanma garantisinin, turistler açısından bilinirliğinin sağlanması tavsiye edilebilir.

- Araştırma bulguları doğrultusunda "bilişsel imaj deneyim kalitesi" boyutunun ortalama sonucu diğer imaj faktörlerine göre daha düşük belirlenmiştir. Bu kapsamda Bodrum destinasyonu için kamu kurumları açısından alt yapı ve güvenlik sorunlarının iyileştirilmesi tavsiye edilebilir. Destinasyonda gerçekleştirilen ve gerçekleştirilecek olan alt yapı ve üst yapı çalışmalarının uygun dönemlerde tamamlanması tavsiye edilebilir. 2020 yılı göz önüne alındığında ise sağlık alanında gerekli alt yapı ve üst yapı olanaklarının iyileştirilmesi ve hem yerel halk hem de turizm açısından Bodrum destinasyonuna yeni sağlık yatırımlarının yapılması tavsiye edilebilir.

- Bu çalışmada değişkenler bir bütün olarak ele alınmış ve değerlendirilmiştir. İleride gerçekleştirilecek olan çalışmalarda değişkenlerin alt boyutlarının etkilerinin tespiti sağlanabilir ve konu ile ilgili ayrıntılı bilgi elde edilebilir. Çalışmada Bodrum destinasyonu ele alınmıştır. Daha sonraki çalışmalarda farklı destinasyonlar ele alınarak araştırma yapılabilir. Çalışmanın destinasyona yönelik belirli bir dönem içerisindeki algıları kapsadığı söylenebilir. Bu açıdan farklı dönemlerde destinasyona yönelik algıların ölçülüp karşılaştırılması sağlanabilir. Çalışma yabancı turistlere yönelik olarak gerçekleştirilmiştir. Gerçekleştirilecek olan çalışmalarda yerli turistlere yönelik araştırma yapılabilir. Çalışmada destinasyon imajı, algılanan risk ve davranışsal niyet değişkenleri ele alınmıştır. Yapılacak olan çalışmalarda destinasyon imajı, algılanan risk ve davranışsal niyet değişkenleri farklı değişkenler ile araştırılabilir. 
Savaşçı U. \& Yıldırım, H. M. (2021). Impact of Destination Image and Perceived Risk on Behavioral Intention:

The Case of Bodrum. GSI Journals Serie A: Advancements in Tourism, Recreation and Sports Sciences (ATRSS), 4 (2): 17-36

\section{Teşekkür ve Bilgi Notu}

Bu makale Çanakkale Onsekiz Mart Üniversitesi, Lisansüstü Eğitim Enstitüsü, Seyahat İşletmeciliği ve Turist Rehberliği Anabilim Dalı’nda tamamlanan “Destinasyon İmajı ve Algılanan Riskin, Davranışsal Niyete Etkisi: Bodrum Örneği” isimli yüksek lisans tezinden üretilmiştir.

\section{Kaynaklar}

An, M., Lee, C. ve Noh, Y. (2010). Risk Factors At The Destination: Their Impact on Air Travel Satisfaction and Repurchase Intention. Service Business, 4(2), 155-166.

Anderson, C. A. (1983). Imagination and Expectation: The Effect of Imagining Behavioral Scripts on Personal Intentions. Journal of Personality and Social Psychology, 45(2), 293-305.

Artuğer, S. (2015). The Effect of Risk Perceptions on Tourists' Revisit Intentions. European Journal of Business and Management, 7(2), 36-43.

Ateşoğlu, İ. ve Türker, A. (2014). Tatil Yeri Seçiminde Ülke İmajının Turistin Risk Algısı Üzerine Etkisi. Uluslararası Alanya İşletme Fakültesi Dergisi, 6(2), 9-28.

Atılgan İnan, E., Akıncı, S., Kıymalıŏglu, A. ve Akyürek, M. S. (2011). Kruvaziyer Turizminde Turistlerin Tavsiye Niyetlerinde Destinasyon İmajının Etkisi. Ege Akademik Bakış Dergisi, 11(3), 487-497.

Baloğlu, S. ve Mccleary, K. W. (1999). A Model of Destination Image Formation. Annals of Tourism Research, 26(4), 868-897.

Bayram, N. (2010). Yapısal Eşitlik Modellemesine Giriş Amos Uygulamaları. Bursa: Ezgi Kitapevi.

Beerli, A. ve Martin, J. D. (2004). Factors Influencing Destination Image. Annals of Tourism Research, 31(3), 657-681.

Berthon, P., Ewing, M. ve Hah, L. L. (2005). Captivating Company: Dimensions of Attractiveness in Employer Branding. Internetional Journal of Advertising, 24(2), 151-172.

Bigne, J. E., Sanchez, M. I. ve Sanchez, J. (2001). Tourism Image, Evaluation Variables and After Purchase Behaviour: Inter-Relationship. Tourism Management, 22(6), 607-616.

Biswakarma, G. (2017). Impact of Destination Image and Perceived Risk on Behavioral Intention of Travelers to Nepal. International Journal of Advanced Research and Publications, 1(5), 62-71.

Chapuis, J. M., Le Falher, C. ve Gonzalez, M. (2015). Destination Image, Perceived Risk and Intention to Visit. SSRN Electronic Journal, 1-19.

Chen, C. F. ve Tsai, D. (2007). How Destination Image and Evaluative Factors Affect Behavioral Intentions?, Tourism Management, 28(4), 1115-1122.

Chen, C. C., Lai, Y. H., Petrick, J. F. ve Lin, Y. H. (2016). Tourism Between Divided Nations: An Examination Of Stereotyping on Destination Image. Tourism Management, 55, 25-36.

Chew, E. Y. T. ve Jahari, S. A. (2014). Destination Image As A Mediator Between Perceived Risks and Revisit Intention: A Case of Post-Disaster Japan. Tourism Management, 40, 382-393.

Coşkun, R., Altunışık, R. ve Yıldırım, E. (2017). Sosyal Bilimlerde Araştırma Yöntemleri SPSS Uygulamalı (9. Bask1). Sakarya: Sakarya Yayınc1lı.

Çetinsöz, B. C. ve Ege, Z. (2013). Impacts of Perceived Risks on Tourists' Revisit Intentions. Anatolia: An International Journal of Tourism and Hospitality Research, 24(2), 173-187. 
Savaşçı U. \& Yıldırım, H. M. (2021). Impact of Destination Image and Perceived Risk on Behavioral Intention:

The Case of Bodrum. GSI Journals Serie A: Advancements in Tourism, Recreation and Sports Sciences (ATRSS), 4 (2): 17-36

Floyd, M. F., Gibson, H., Pennington-Gray, L. ve Thapa, B. (2004). The Effect of Risk Perceptions on Intentions to Travel in The Aftermath of September 11, 2001. Journal of Travel \& Tourism Marketing, 15(2-3), 19-38.

Fornell, C. ve Larcker, D. F. (1981). Evaluating Structural Equation Models with Unobservable Variables and Measurement Error. Journal of Marketing Research, 18(1), 39-50.

Frewer, L. J., Hunt, S., Brennan, M., Kuznesof, S., Ness, M. ve Ritson, C. (2003). The Views of Scientific Experts on How The Public Conceptualize Uncertainty. Journal of Risk Research, 6(1),75-85.

Fuchs, G. ve Reichel, A. (2006). Tourist Destination Risk Perception: The Case of Israel. Journal of Hospitality $\mathcal{E}$ Leisure Marketing, 14(2), 83-108.

Gao, H. (2006, September). Research on components of consumer perceived risk. In 2006 IEEE International Engineering Management Conference (pp. 334-335). IEEE.

Gartner, W. B. (1989). "Who Is An Entrepreneur?" Is The Wrong Question. American Journal of Small Business, 13, 47-67.

Gronhaug, K. (1972). Risk Indicators, Perceived Risk and Consumer's Choice of Information Sources. The Scandinavian Journal of Economics, 74(2), 246-262.

Hair., J. F., Black, W. C., Babin, B. J. ve Anderson, R. E. (2014). Multivariate Data Analysis (7. Ed.). U.S.A.: Pearson Education Limited.

Hair, J. F., Hult, G. T. M., Ringle, C. M. ve Sarstedt, M. (2016). A Primer on Partial Least Squares Structural Equation Modeling (PLS-SEM), (2. Baskı). U.S.A: Sage Publications.

Harun, A., Obong, A., Kassim, A. W. M. ve Lily, J. (2018). The Effects of Destination Image and Perceived Risk on Revisit Intention: A Study in The South Eastern Coast of Sabah, Malaysia. E-Review of Tourism Research, 15(6), 540-559.

Hasan, Md. K., Ismail, A. R. ve Islam, M. F. (2017). Tourist Risk Perceptions and Revisit Intention: A Critical Review of Literature. Cogent Business \& Management, 4(1), 1-21.

Hosany, S., Ekinci, Y. ve Uysal, M. (2007). Destination Image and Destination Personality. International Journal of Culture, Tourism and Hospitality Research, 1(1), 62-81.

Hunter-Jones, P., Jeffs, A. ve Fischbacher-Smith, D. (2008). Backpacking Your Way Into Crisis: An Exploratory Study Into Perceived Risk and Tourist Behaviour Amongst Young People. Journal of Travel \& Tourism Marketing, 23(2-4), 237-247.

İlhan, M. ve Çetin, B. (2014). LISREL ve AMOS Programları Kullanılarak Gerçekleştirilen Yapısal Eşitlik Modeli (YEM) Analizlerine İlişkin Sonuçların Karşılaştırılması. Eğitimde ve Psikolojide Ölçme ve Değerlendirme Dergisi, 5(2), 26-42.

Jacoby, K. L. The Components of Perceived Risk Proceedings. 1972. In Third Annual Conference Association for Consumer Research. Chicago: University of Chicago.

Khasawneh, M. S. ve Alfandi, A. M. (2019). Determining Behaviour Intentions from The Overall Destination Image and Risk Perception. Tourism and Hospitality Management, 25(2), 355-375.

Kline, R. B. (1998). Methodology in The Social Sciences. Principles and Practice of Structural Equation Modeling. New York, Guilford Press.

Koo, S. K., Byon, K. K. ve Baker, T. A. (2014). Integrating Event Image, Satisfaction and Behavioral Intention: Small-Scale Marathon Event. Sport Marketing Quarterly, 23, 127-137.

Kozak, M., Crotts, J. C. ve Law, R. (2007). The Impact of The Perception of Risk on International Travellers. International Journal of Tourism Research, 9(4), 233-242. 
Savaşçı U. \& Yıldırım, H. M. (2021). Impact of Destination Image and Perceived Risk on Behavioral Intention: The Case of Bodrum. GSI Journals Serie A: Advancements in Tourism, Recreation and Sports Sciences (ATRSS), 4 (2): 17-36

Kozak, M. (2015). Bilimsel Araştırma: Tasarım, Yazım ve Yayım Teknikleri (2.Baskı). Ankara: Detay Yayıncilik.

Lim, N. (2003). Consumers' Perceived Risk: Sources Versus Consequences. Electronic Commerce Research and Applications, 2(3), 216-228.

Loi, L. T. I., So, A. S. I., Lo, I. S. ve Fong, L. H. N. (2017). Does The Quality of Tourist Shuttles Influence Revisit Intention Through Destination Image and Satisfaction? The Case of Macao. Journal of Hospitality and Tourism Management, 32, 115-123.

Makhdoomi, U. M. ve Baba, M. M. (2019). Destinastion Image and Travel Intention of Travellers to Jammu \& Kashmir: The Mediating Effect of Risk Perception. Journal of Hospitality Application $\mathcal{E}$ Research, 14(1), 35-56.

Meydan, C. H. ve Şeşen, H. (2015). Yapısal Eşitlik Modellemesi AMOS Uygulamaları. Ankara: Detay Yayıncilik.

Mitchell, V. W. ve Vassos, V. (1998). Perceived Risk and Risk Reduction in Holiday Purchases: A CrossCultural and Gender Analysis. Journal of Euromarketing, 6(3), 47-79.

Muğla İl Kültür ve Turizm Müdürlüğü, Turizm İstatistikleri, https://mugla.ktb.gov.tr/TR-73710/turizmistatistikleri.html (Erişim Tarihi: 09.02.2020).

Özdemir, G. (2008). Destinasyon Pazarlaması. Ankara: Detay Yayıncılık.

Perpina, L., Camprubi, R. ve Prats, L. (2019). Destination Image Versus Risk Perception. Journal of Hospitality \& Tourism Research, 43(1), 3-19.

Pike, S. (2002). Destination Image Analysis -A Review Of 142 Papers From 1973 to 2000. Tourism Management, 23(5), 541-549.

Reisinger, Y. ve Mavondo, F. (2005). Travel Anxiety and Intentions to Travel Internationally: Implications of Travel Risk Perception. Journal of Travel Research, 43(1), 212-225.

Roehl, W. S. ve Fesenmaier, D. R. (1992). Risk Perceptions and Pleasure Travel: An Exploratory Analysis. Journal of Travel Research, 2(4), 17-26.

Schiffman, L. G. ve Kanuk, L. L. (2000). Consumer Behavior. New Jersey: Prentice-Hall.

Sevim, B., Seçilmiş, C. ve Görkem, O. (2013). Algılanan Destinasyon İmajının Tavsiye Davranışı Üzerine Etkisi: Safranbolu'da Bir Araştırma. Uluslararası Yönetim İktisat ve İşletme Dergisi, 9(20), 115-129.

Stepchenkova, S. ve Morrison, A. M. (2008). Russia's Destination Image Among American Pleasure Travelers: Revisiting Echtner and Ritchie. Tourism Management, 29(3), 548-560.

Stylos, N., Vassiliadis, C. A,; Bellou, V. ve Andronikidis, A. (2016). Destination Images, Holistic Images and Personal Normative Beliefs: Predictors of Intention to Revisit A Destination. Tourism Management, 53, 40-60.

Şimşek, M. ve Özdamar, M. (2020). Yerli Turistlerin Destinasyon İmajları ile Davranışsal Niyetleri Arasındaki İlişkinin İncelenmesi: Mersin Örneği. Türk Turizm Araştırmaları Dergisi, 4(2), 811-822.

Tavitiyaman, P. ve Qu, H. (2013). Destination Image and Behavior Intention of Travelers to Thailand: The Moderating Effect of Perceived Risk. Journal of Travel \& Tourism Marketing, 30(3), 169-185.

Tsaur, S. H., Tzeng, Gwo-Hshiung ve Wang, Kuo-Ching (1997). Evaluating Tourist Risks from Fuzzy Perspectives. Annals of Tourism Research, 24(4), 796-812.

Ural, A. ve Kılıç, İ. (2013). Bilimsel Araştırma Süreci ve SPSS ile Veri Analizi (4.Baskı). Ankara: Detay Yayıncilik. 
Savaşçı U. \& Yıldırım, H. M. (2021). Impact of Destination Image and Perceived Risk on Behavioral Intention:

The Case of Bodrum. GSI Journals Serie A: Advancements in Tourism, Recreation and Sports Sciences (ATRSS), 4 (2): 17-36

Wang, C. Y. ve Hsu, M. K. (2010). The Relationships of Destination Image, Satisfaction and Behavioral Intentions: An Integrated Model. Journal of Travel \& Tourism Marketing, 27(8), 829-843.

Warshaw, P. R. ve Davis, F. D. (1985). Disentangling Behavioral Intention and Behavioral Expectation. Journal of Experimental Social Psychology, 21(3), 213-228.

West, S. G., Finch, J. F. ve Curran, P. J. (1995). Structural Equation Models with Nonnormal Variables: Problems and Remedies. In R. H. Hoyle (Ed.), Structural Equation Modeling: Concepts, Issues, and Applications (p. 56-75). Thousand Oaks, Sage Publications.

Yang, J., Gu, Y. ve Cen, J. (2011). Festival Tourists'Emotion, Perceived Value, and Behavioral Intentions: A Test of The Moderating Effect of Festivalscape. Journal of Convention E Event Tourism, 12(1), 25-44.

Yüce, A., Samsa, Ç. ve Meriç, K. (2019). Destinasyon İmajının Tekrar Ziyaret Etme Niyeti Üzerine Etkisi: Kars İli Örneği. Kafkas Üniversitesi İktisadi ve İdari Bilimler Fakültesi Dergisi, 10(19), 131-150.

Zeithaml, V. A., Berry, L. L. ve Parasuraman, A. (1996). The Behavioral Consequences of Service Quality. Journal of Marketing, 60(2), 31-46.

Zhang, H., Fu, X., Cai, L. A. ve Lu, L. (2014). Destination Image and Tourist Loyalty: A Meta-Analysis. Tourism Management, 40, 213-223.

Zhang, H., Wu, Y. ve Buhalis, D. (2018). A Model of Perceived Image, Memorable Tourism Experiences and Revisit Intention. Journal of Destination Marketing E Management, 8, 326-336. 